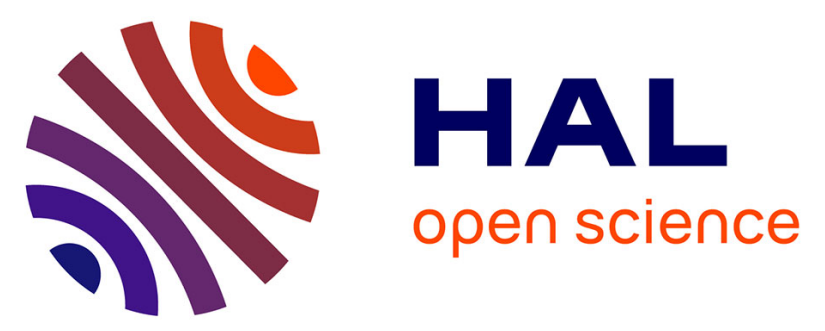

\title{
Paving the way for sustainable bioenergy in Europe: technological options and research avenues for large-scale biomass feedstock supply
}

Benoit Gabrielle, Laure Bamière, Natalia Caldes, Stéphane de Cara, Guillaume Decocq, Fabien Ferchaud, Chantal Loyce, Elise Pelzer, Y. Perez, Julie Wohlfahrt, et al.

\section{To cite this version:}

Benoit Gabrielle, Laure Bamière, Natalia Caldes, Stéphane de Cara, Guillaume Decocq, et al.. Paving the way for sustainable bioenergy in Europe: technological options and research avenues for largescale biomass feedstock supply. Renewable and Sustainable Energy Reviews, 2014, 33, pp.11 - 25. 10.1016/j.rser.2014.01.050 . hal-01173026v2

\section{HAL Id: hal-01173026 \\ https://hal.science/hal-01173026v2}

Submitted on 7 May 2013

HAL is a multi-disciplinary open access archive for the deposit and dissemination of scientific research documents, whether they are published or not. The documents may come from teaching and research institutions in France or abroad, or from public or private research centers.
L'archive ouverte pluridisciplinaire HAL, est destinée au dépôt et à la diffusion de documents scientifiques de niveau recherche, publiés ou non, émanant des établissements d'enseignement et de recherche français ou étrangers, des laboratoires publics ou privés. 
1 Paving the way for sustainable bioenergy in Europe: technological options and

2 research avenues for large-scale biomass feedstock supply

3

4 Running title: Sustainable biomass supply in Europe

5

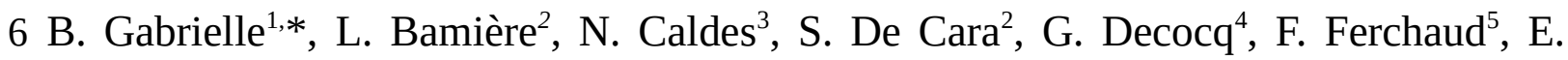

7 Pelzer $^{6}$, C. Loyce ${ }^{7}$, Y. Perez ${ }^{3}$, J. Wohlfahrt ${ }^{8}$, G. Richard ${ }^{9}$

8

9 1: AgroParisTech, INRA, UMR 1091 Environnement et Grandes Cultures, F-78850

10 Thiverval-Grignon, France.

11 2: INRA, AgroParisTech, UMR 210 Economie Publique, F-78850 Thiverval-Grignon,

12 France.

13 3: CIEMAT. Energy System Analysis Unit. Energy department. Avda Complutense 40, 1428040 Madrid. Spain.

15 4: UPJV, CNRS, UR Ecologie et Dynamique des Systèmes Anthropisés (EDYSAN, FRE 16 3498), Amiens, France.

17 5: INRA, UPR1158 AgroImpact, site de Laon, F-02000 Barenton-Bugny, France

18 5: INRA, UMR 211 Agronomie, F-78850 Thiverval-Grignon, France

19 6: AgroParisTech, UMR 211 Agronomie, F-78850 Thiverval-Grignon, France

20 8: INRA, UR 055 SAD ASTER, F-88500 Mirecourt, France.

21 9: INRA, Environment \& Agronomy Department, F-45 075 Orléans, France.

23 * Corresponding author. Tel.: +33 1308155 51; Fax: +331 30815563 
$24 \quad$ E-mail address: Benoit.Gabrielle@agroparistech.fr

25

26

27 Keywords: Biofuels, Bioenergy, Sustainability, Energy crops, Feedstock supply,

28 Greenhouse gas emissions, Land-use change

29

30 


\section{ABSTRACT}

32 Biomass is expected to be a major player in the energy transition toward low-carbon

33 economies, in response to the pressing challenges of climate change and dwindling fossil

34 resources. Meeting the ambitious recently set for bioenergy development worldwide involve a

35 several-fold increase in biomass production, and poses major challenges for feedstock supply

36 chains in terms of competitiveness, reliability and sustainability.

37 This paper reviews current knowledge on the sustainability of agricultural feedstock supply

38 chains and emphasize future research needs. It covers the range of feedstocks currently

39 available in an European context, from arable crops to perennial lignocellulosic plants, and

40 the various dimensions of sustainability: environmental and ecological, economic and social.

41 Knowledge gaps and technological options to assess and meet sustainability criteria are

42 reviewed from plot to landscape and global scales.

43 Bioenergy feedstocks present a wide range of dry matter yields, agricultural input

44 requirements and environmental impacts, depending on crop type, management practices, and 45 soil and climate conditions. Their integration into farmers' cropping systems poses specific 46 challenges in terms of environmental impacts, but also opportunities for improvements via the 47 use of grass-legume intercropping or residues from biomass conversion processes. Taking into 48 account the spatial distribution of bioenergy crops is paramount to assessing their 49 environmental impacts, in particular on biodiversity, or the food versus energy competition 50 issue. However, few modelling frameworks convey the full complexity of the underlying 51 processes and drivers, whether economic, social or biophysical. In particular, social impacts 52 of bioenergy projects are seldom assessed and there is no methodological consensus.

53 The main research areas identified involve: multi-crop and multi-site experiments, along with 54 modelling, to optimise management practices and cropping systems producing bioenergy, 55 possibly on alternative lands and under future climate changes; the design of innovative 
56 cropping systems using expert knowledge to ensure suitable integration into farmers' cropping 57 systems; the collection of detailed data on the location of bioenergy crops to validate 58 theoretical modelling frameworks and improve sustainability assessment; tackling direct and 59 indirect effects of bioenergy development on land-use changes via coupled economic and 60 agronomical models; investigating the effect of perennial stands on biodiversity in relation to 61 previous land-use and landscape structure; and further developing currently-available 62 methodologies to fully appraise the social implications of bioenergy projects.

63

64

65

66 


\section{Introduction}

68 Biomass is expected to be a major player in the energy transition toward low-carbon

69 economies, in response to the pressing challenges of climate change and dwindling fossil 70 resources. According to the recent IPCC scenarios of energy transition, bioenergy may 71 contribute up to half of total use of primary energy worldwide by 2050 [1]. Such high 72 expectations are reflected in the ambitious bioenergy targets recently set in the EU, the US, 73 Brazil or India, with bioenergy being attributed a $20 \%$ to $30 \%$ share of the overall energy mix 74 within the next 20 years. This implies a several-fold increase compared to the present 75 production of bioenergy, and poses major challenges for agriculture and forestry, since this 76 expansion will for a large part rely on dedicated energy plants, including lignocellulosic crops 77 and short rotation forestry [2]. In Europe for instance, bio-energy is the fastest growing 78 renewable energy source with a production that almost doubled over the last 15 years, 79 currently supplying 6\% of the total primary energy [3]. Around 3.1 Mha in the European 80 Union (EU) are currently used for bioenergy, mainly for biofuel production as biodiesel and 81 ethanol, and biogas, all involving arable food and feed crops. A small proportion is derived 82 from dedicated bioenergy crops. These crops are mostly perennials grown to generate 83 electricity and heating, with the most frequent species being miscanthus, willow, reed canary 84 grass and poplar. They were covering 50000 to 60000 ha in Europe in 2008, and about 100 85000 ha in 2010 [4,3], underlining a rapid development. Such trend is likely to continue since it 86 is estimated that 17-19 million hectares should be converted to bio-energy crops to meet the 87 targets of the SET-plan in the EU, whether for heat, electricity of liquid biofuels production 88 [3]. Meeting this demand raises considerable challenges for feedstock supply chains in terms 89 of competitiveness, reliability and sustainability [5]. First, the availability of terrestrial land to 90 grow the feedstock imposes major constraints on potential biomass supply, and secondly the 91 conditions for a sustainable and reliable supply are yet to be defined [6]. 
93 environmental, ecological, economic and social issues, together with human health [2].

94 Environmental impacts encompass water availability and quality, soil and air quality, 95 biodiversity and climate through the emissions of greenhouse gases (GHG) and C 96 sequestration in soils (e.g., 7-8). Following the controversy on the GHG benefits of first 97 generation biofuels [9], concerns have also been raised for lignocellulosic crops [6], mostly 98 pointing at our limited knowledge of their environmental and economic performances. The above-mentioned societal concerns with biomass have pressed the need for a

100 certification of bioenergy chains, encompassing environmental, social and economic aspects 101 [10], with the challenge that many of the underlying processes and impacts are still debated in 102 the scientific community (eg, 11). Figure 1 attempts at summarizing the performance criteria 103 underlying these certification schemes, reflecting the expectations of both society at large and 104 economic stakeholders for bioenergy, with a focus on feedstock production and supply which 105 concentrates most of the sustainability-related challenges and is the actual scope of this paper.

106 The criteria are combined with the relevant scales (from field to global) on which they should 107 be addressed. Upscaling (from plot-scale to regional and possibly global scale) therefore 108 appears critical in the design and assessment of bioenergy projects. Most sustainability assessments of bioenergy chains currently focus on the

110 environmental impacts, and more specifically on GHG and energy balances [7,12]. Given the 111 relevance of the socio-economic impacts of bio-energy, the latter are now present in most 112 certification schemes [11]. However, economic and social criteria are seldom addressed, let 113 alone combined with the environmental assessment [12]. Environmental impacts are usually 114 quantified using life-cycle assessment (LCA) whose outcomes vary widely across studies for 115 seemingly similar pathways $[2,13]$. Other environmental impacts such as eutrophication or 116 tropospheric ozone formation are sometimes included [14], but are rarely connected with the 
117 local conditions of feedstock production. However, the latter actually contributes a major

118 share of the variability in the impacts of bio-energy chains [15].

120 important but still poorly evaluated changes in processes maintaining biodiversity in both

121 space and time, which should be addressed at the field and landscape scales [16-18].

122 Upscaling from plot to landscape level is also necessary to properly address the other

123 categories of environmental impacts, which implies and upscaling of input data and/or

124 upscaling modelled processes [19]. The 'cascade' of $\mathrm{N}$ flows and impacts in the landscapes

125 provides a prime example of these challenges [20], and is a source of indirect emissions of $126 \mathrm{~N}_{2} \mathrm{O}$ (a potent greenhouse gas) for crops outside the cultivation field which came into sharp 127 focus for biofuels lately [11].

128 Compared to food crops, the economics of lignocellulosic crops are particular in that 129 they have higher dry matter yields and lower input levels, but higher establishment and land 130 costs. These traits determine the outcome of the competition with food crops for land and the 131 availability of biomass feedstock for bioenergy conversion units, but are seldom fully 132 accounted for when assessing biomass potentials. This results in a large variation of estimates 133 for biomass potentials [21], which should be addressed by accounting for land use 134 competition and substitution, policy constraints, the spatial distribution of bioenergy crops 135 and other feedstock types (including forest products), and logistics constraints [22]. 136 Approaches that account for spatial and temporal variations of feedstock supply are also 137 warranted to gain a better insight into the overall competitiveness of bioenergy based on 138 lignocellulosic biomass, which is still debated [2].

139 Social implications of bio-based projects are important both in terms of public 140 perception of the risks and opportunities of these projects, and of the technical and 141 organisational innovations necessary for their successful implementation [22]. The spreading 
142 and uptake of new knowledge is necessary, regarding the farming of crops as well as the

143 forms of organisation to be set up over the feedstock supply area and the biomass value-chain.

144 However, there is a paucity of specific social sustainability assessment methodologies. Up to

145 now, assessments have often been conducted through social impact assessment (SIA), 146 extended to include other sustainability pillars, or by extending the framework of 147 environmental impact assessment (EIA) to incorporate social issues.

148 The objective of this paper is to review current knowledge on the sustainability of 149 agricultural feedstock supply chains and emphasize research needs for i/ a more reliable 150 assessment of their impacts and ii/ establishing guidelines to improve their performance and 151 ultimately provide guidance to stakeholders and policy-makers. The paper reviews all 152 components of the feedstock supply chains, from feedstock production in agricultural fields to 153 the supply-area scale including the drivers of biomass production. It points at the key issues 154 and interlinkages between these components in terms of sustainability and practical feasibility 155 (Figure 1).

\section{Feedstock production and environmental impacts}

\section{Biomass and biofuel yields}

158 Current and near-term conversion technologies lead to a wide range of candidate crops among

159 which short rotation coppices [5], perennial rhizomatous grasses [23], pluriannual forage 160 crops [24] and annual crops [25]. Crop residues such as corn stover or wheat straw are also an 161 abundant source of biomass which could be used for bioenergy production [26]. Table 1 162 reviews the yields of the most investigated dedicated bioenergy crops in each category and 163 compares them to the yields currently achieved by the main conventional crops used for 164 bioenergy production and their residues. Yields are expressed in dry matter and in toe (tons of 165 oil equivalent) in the case of biofuel production, using commercial conversion yields for first 
166 generation biofuels and expected conversion yields of cellulosic ethanol for dedicated crops 167 and crop residues (Table S1).

168 The yields of arable crops were evaluated using available agricultural statistics since there is 169 no or little difference between the cultivars and crop management practices used for food or 170 bioenergy production. We focused on three different scales: EU-27, France, and an 171 administrative department (6170 km² in area) called "Somme” in northern France, in a region 172 of intensive arable crop production. The hierarchy between crops was identical across the 3 173 scales, with sugar-beet being the most productive crop and oilseed rape the less productive. 174 This ranking also applied to biofuel production, with an output approximately 3 times higher 175 for sugar-beet than for oilseed rape per ha, even though the latter has the highest grains to 176 biofuel conversion yield.

177 The biomass production potential of dedicated lignocellulosic crops has mostly been 178 investigated in experimental plots, mainly in Europe and North America, and involving only 179 one crop type, which makes it difficult to compare crops. As a consequence, dry matter yields 180 found in the literature (Table 1) should not be used to rank crops because of the differences in 181 soil and climate conditions between studies. For instance, fiber sorghum was only 182 investigated in southern Europe whereas willow data originate from northern Europe. The 183 large variability in the literature data for a given crop type (Table 1) also arises from 184 differences in crop management (eg, irrigation and fertilizer inputs) between studies. For the 185 scale of France, Table 1 displays the results of an experimental network (called "Regix”) 186 comparing 6 species in 10 sites located in northern, central and southern France [27]. The data 187 evidence a large variability between sites, due to the interaction between crops and soil and 188 climate conditions, with no consistent ranking of crops across the network of sites. At 189 departmental scale in Somme, the data of Table 1 were obtained in a single experimental site 190 with a soil representative of this area [28]. In this site, the perennial rhizomatous crops 
191 miscanthus and switchgrass were the most productive, particularly when harvested in autumn.

192 The conversion yields (CY) given in Table 1 for cellulosic ethanol production (in tons of oil 193 equivalent (toe) per ton of feedstock dry matter - DM) are generally smaller than those 194 recorded for first generation biofuels ( 0.09 to 0.18 toe $\mathrm{t}^{-1} \mathrm{DM}$ vs. 0.22 to 0.40 toe $\mathrm{t}^{-1} \mathrm{DM}$ ). 195 Conversion yields vary according to the biochemical composition of biomass (Table S1), 196 being higher for triticale, short rotation coppices (SRC) and perennial rhizomatous crops, and 197 smaller for multiannual forage crops. In the French experimental network, biofuel yields per 198 ha were generally higher for perennial rhizomatous crops and triticale than for the other crops 199 (Table 1). In the Somme department, biofuel yields per ha were higher for perennial 200 rhizomatous crops, lower for pluriannual forage crops and intermediate for annual crops.

201 Crop residue production from conventional crops is estimated in Table 1, using grain/straw 202 ratios from [29]. Residue yields are in the same order of magnitude as grain yields, but biofuel 203 yields per ha are approximately one third lower than grains because of lower conversion 204 yields.

205 Biofuel yields for various feedstocks may be compared in the case of the Somme department, 206 characterized by deep loamy soils, temperate climate and intensive agricultural practices. The 207 highest yield is achieved by the perennial crop miscanthus harvested in autumn (4.3 toe ha ${ }^{-1}$ $208 \mathrm{yr}^{-1}$ ) but sugar beet is the second more productive crop with 3.9 toe $\mathrm{ha}^{-1} \mathrm{yr}^{-1}$ and whole-plant 209 maize the third more productive with 3.3 toe $\mathrm{ha}^{-1} \mathrm{yr}^{-1}$. The other crops rank as follow: 210 miscanthus harvested in winter and switchgrass > dedicated annual crops and other

211 conventional crops (whole plant) > conventional grain crops > pluriannual forage crops.

\section{Agricultural input requirements}

214 Conventional crops are highly dependent on agricultural inputs, particularly chemical 
215 fertilizers and pesticides. Crop nutrient requirements are of prime importance because 216 nitrogen fertilization has a huge impact of the overall GHG balance of bioenergy crops [11] 217 and because $\mathrm{P}$ and $\mathrm{K}$ are non-renewable resources that cannot be synthesized. In France in 218 2006, the mean fertilization rates for winter wheat, maize, oilseed rape and sugar beet were

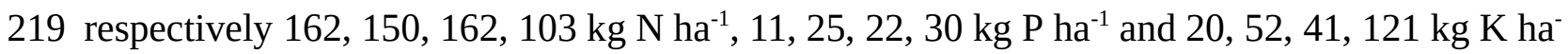
$220{ }^{1}[30]$.

221 The nutrient requirements of lignocellulosic crops are still poorly known. The yield response 222 of perennial crops to nitrogen fertilization varies between sites. For miscanthus, out of 11 223 studies reviewed by Cadoux et al. [31], 6 concluded to a positive but often limited response 224 (an increase of 1 to $6 \mathrm{t} \mathrm{DM} \mathrm{ha}^{-1}$ in autumn), while 5 showed an absence of a response. The 225 same variability was shown for switchgrass by Monti et al. [32], who reviewed 6 studies with 22610 locations in the USA. No response or an increase of less than $2 \mathrm{t} \mathrm{DM} \mathrm{ha-1}$ was observed in 2274 sites while in 6 sites an increase of 2 to $11 \mathrm{t} \mathrm{DM} \mathrm{ha}^{-1}$ was observed. Among pluriannual 228 forage crops, alfalfa does not require $\mathrm{N}$ inputs because of its $\mathrm{N}$-fixing capacity [33], while the $229 \mathrm{~N}$ requirements of fescue are high [34]. For annual crops, the yield triticale was shown to 230 increase with $\mathrm{N}$ fertilization in 4 locations in Southwest Germany, which is consistent with the 231 relatively high $\mathrm{N}$ requirements of this crop [35]. Surprisingly, no effects of $\mathrm{N}$ inputs on the 232 yield of fiber sorghum were evidenced in a field trial in northern Italy [36]. Finally, unlike 233 nitrogen, the role of $\mathrm{P}$ and $\mathrm{K}$ as possible limiting factor of biomass yields has been little 234 investigated for lignocellulosic crops [37].

235 An indirect way of assessing the nutrient requirements of crops is to compare nutrient 236 concentrations at harvest. For a given crop type, the latter can vary because of differences in 237 soil nutrient availability, crop management (harvest time, fertilization) and DM yield. Despite 238 this variability, literature data show that nutrient concentrations are crop-specific and very 239 variable between feedstocks (Table 2). Across the crops considered in this Table, $\mathrm{N}$ 
240 concentration varies between 3.3 and $31.8 \mathrm{~g} \mathrm{~N} \mathrm{~kg}^{-1} \mathrm{DM}$, P concentration between 0.4 and $6 \mathrm{~g}$

$241 \mathrm{P} \mathrm{kg}^{-1}$ and $\mathrm{K}$ concentration between 2.1 and $21.4 \mathrm{~g} \mathrm{~K} \mathrm{~kg}^{-1}$. This variability also exists between

242 arable crops, with sugar-beet having much smaller $\mathrm{N}$ and $\mathrm{P}$ concentration than the other crops

243 and especially oilseed rape. The differences in N, P and K concentrations between these crops

244 are consistent with the observed mean fertilization rates expressed per ton of harvested

245 biomass. Overall, the highest $\mathrm{N}$ concentrations are observed for arable crops except for sugar-

246 beet and forage crops, and the lowest $\mathrm{N}$ concentrations are observed for SRC and perennial

247 rhizomatous crops. The same trend applies to P concentrations, with crop residues having also

248 very low P concentrations. For K, forage crops have the highest concentrations, followed by

249 crop residues, while SRC willow and poplar have the lowest concentrations.

250 Conversion yields presented in Table 1 were used to calculate the amount of nutrient removed 251 from the field per toe of biofuel produced (Table 2). It highlights the advantages of SRC, 252 perennial rhizomatous crops, crop residues and also sugar beet, which export less $\mathrm{N}$ and $\mathrm{P}$ per 253 toe of biofuel produced than the other feedstocks.

254 Pesticide requirements are another concern when choosing a type of feedstock. Agricultural 255 surveys show a high level of pesticide use for arable crops with however a large variability 256 between crops. For example, the mean number of pesticide applications was 4.0 for wheat, 1.9 257 for maize, 6.1 for oilseed rape and 4.2 for sugar-beet in France in 2006 [38]. Pesticide use is 258 likely to be reduced with lignocellulosic crops, particularly with SRC, perennial and 259 pluriannual crops which only require herbicide application during the establishment phase, 260 and no pesticide applications afterwards.

261 Another advantage of perennial crops is that they require less cultural operations than annual 262 crops. Thus, they reduce the use of fossil energy and the associated GHG emissions by a 263 factor of 3 to 5 compared to annual food crops [39]. 


\section{Environmental impacts}

265 The choice of a given feedstock has implications on its environmental impacts at the field 266 scale. Among them, biosphere-atmosphere exchanges of GHG in the field a crucial item for 267 the overall GHG balance of bioenergy chains. The main fluxes include soil $\mathrm{N}_{2} \mathrm{O}$ emissions 268 and $\mathrm{CO}_{2}$ balance, as controlled by changes in soil and biomass $\mathrm{C}$ pools [3]. Although there is 269 a large body of work on these fluxes for arable crops, little data is available for lignocellulosic 270 crops. In their review, Don et al. [3] presented the results of 5 European studies comparing $271 \mathrm{~N}_{2} \mathrm{O}$ emissions from arable and perennial lignocellulosic crops (willow SRC, poplar SRC and 272 miscanthus), concluding the latter had significantly lower $\mathrm{N}_{2} \mathrm{O}$ emissions than the former. 273 This was not only an effect of lower $\mathrm{N}$ input rates with perennial crops but also of the 274 reduction of the ratio of emissions to fertilizer rates (emission factor). However, in one of the 2755 sites, the emission factor for miscanthus was more than 3 times higher than for winter rye 276 [40]. A recent study comparing GHG emissions from miscanthus, willow and maize at two 277 fertilization rates (0-240 $\mathrm{kg} \mathrm{N} \mathrm{ha}^{-1}$ for maize and 0-80 $\mathrm{kg} \mathrm{N} \mathrm{ha}^{-1}$ for miscanthus and willow) 278 also lead to contrasted conclusions [41]. The emission factors were $0.95 \%$ for maize, $1.1 \%$ for 279 miscanthus and only $0.04 \%$ for willow. Two other recent studies showed a large increase of $280 \mathrm{~N}_{2} \mathrm{O}$ emissions from perennial crops (miscanthus and switchgrass) with increasing fertilizer $\mathrm{N}$ 281 input rates [42,43]. It seems that the latter are a key point for controlling $\mathrm{N}_{2} \mathrm{O}$ emissions from 282 perennial bioenergy crops and that a balance has to be found between increasing biomass 283 yields and minimizing $\mathrm{N}_{2} \mathrm{O}$ emissions per ton of feedstock produced.

284 Changes in soil organic carbon (SOC) content depends on crop type and management but also 285 on the former land-use history. Conversion of forest or grassland to annual crops leads to very 286 high SOC losses, creating a carbon debt equivalent to 17 to 420 times the annual GHG 287 reduction resulting from the displacement of fossil fuel by first generation biofuels [44]. 288 Increasing the cultivation of whole-plant annual lignocellulosic crops or the rates of residue 
289 removal from arable cropping systems are also likely to decrease SOC stocks [15, 45]. In 290 contrast, the shift from annual crop to SRC or perennial grasses may increase SOC stocks 291 (Anderson-Teixeira et al. 2009), with large variations in C sequestration rates [3]. Climate and 292 soil conditions as well as crop management (e.g. fertilization, harvest time) are likely to 293 impact SOC sequestration [46]. Finally, the fate of this sequestered C after the end of the 294 plantation deserves further investigation.

295 Another major environmental issue with bioenergy feedstocks involves water bodies, from 296 either a quantitative or qualitative point of view. In agricultural landscapes, crop water 297 consumption is an important component of the hydrological cycle. For a given climate, there 298 are differences in water consumption among arable crops, mainly due to the duration and 299 position within the year of their growth cycle. In temperate climates like northern France, 300 spring crops like maize and sugar beet often have a higher water use than winter crops like 301 wheat and oilseed rape. This higher water consumption during crop growth reduces the 302 amount of water drained during the following winter and discharge to aquifers [47]. Lower 303 drainage under forage crops, with long growth cycle and deep root system like alfalfa, than 304 under annual crops has also been observed [48]. Perennial bioenergy crops may also have 305 higher water consumption than annual crops, because of their long growing season and deep 306 root system, and thus reduce drainage [49]. Field studies conducted in the Midwest US have 307 shown higher water use by miscanthus than maize but this was not necessary the case for 308 switchgrass [50, 51]. From a qualitative standpoint, crop type can also affect nitrate leaching. 309 For example, sugar-beet has a capacity to take up nitrate in autumn during a longer period 310 than other crops (eg, maize), and thus reduces nitrate leaching the following winter [47]. 311 However, nitrate leaching is also dependent on crop management and on cropping systems 312 (crop rotation, catch crop, etc.), making it difficult to compare annual crops. Studies 313 investigating nitrate leaching under perennial bioenergy crops concluded to low amounts of 
314 nitrogen leached under established miscanthus, switchgrass or willow SRC, with nitrate 315 concentration in drainage water usually bellow $25 \mathrm{mg} \mathrm{NO3}^{-1}$ [51, 52, 53, 54 55, 56]. Nitrate 316 concentration was little affected by the $\mathrm{N}$ input rates, except in one study with miscanthus for 317 the highest $\mathrm{N}$ rate [53]. However, high nitrate concentrations were observed during the 318 establishment phase of miscanthus and SRC willow (one or two years after establishment), 319 with nitrate concentrations in some cases higher than $100 \mathrm{mg} \mathrm{l}^{-1}$. This was probably due to an 320 imbalance between the soil mineralization rate and the low $\mathrm{N}$ uptake rates of these crops in 321 this period. Another increase in nitrate concentration was also observed after the destruction 322 and replanting of a SRC [54].

324 In conclusion, bioenergy crops present a wide range of biomass production per unit area and 325 input requirements per ton of feedstock. Their environmental impacts are also variable 326 depending on crop type, management practices and soil and climate conditions. There is thus 327 a need to better quantify their productivity in relation to soil and climate conditions, and to 328 determine optimized cultural practices combining high biomass production and low 329 environmental impacts. The crop-management-site interactions emphasize the need for multi330 crops, multi-practices and multi-local experiments (regarding both biomass production and 331 environmental impacts) and for the development of soil-crop models adapted to these new 332 crops to generalize plot-scale results to larger areas.

\section{Impacts on biodiversity}

334 While annual crops have been extensively studied with respect to their impact on biodiversity,

335 fewer studies address the impacts of lignocellulosic plants. Yet, the introduction of perennial 336 bioenergy crops in a European agricultural landscape dominated by annual crops will 337 certainly lead to marked changes to agrosystems and arable landscapes, especially when 
338 perennial crops such as miscanthus or switchgrass, and/or short rotation coppices of woody 339 species, such as poplars or willows, will be grown besides annual crops. It is likely that 340 processes maintaining biodiversity in both space and time would subsequently change, but 341 this remains largely under-evaluated.

342 First of all, direct or indirect land use change due to expansion of biofuel cultivation may 343 cause deforestation and destroy semi-natural habitats such as grasslands $[57,58]$, which in 344 turn may lead to the loss of biodiversity $[59,60]$. This has been extensively documented in 345 several tropical regions around the world, but remains exceptional in Europe [61]. The 346 situation strongly differs when bioenergy crops are grown on arable lands. In our 347 contemporary agricultural landscapes, arable weeds and their associated invertebrates have 348 dramatically declined due to the heavy use of agrochemicals, especially pesticides. Since 349 lignocellulosic crops have the great advantages of requiring a single initial planting and no 350 major chemical inputs, they are thought to be beneficial to biodiversity.

351 Comparing miscanthus to reed canary-grass (Phalaris arundinacea), Semere \& Slater [16, 17] 352 found that ground beetles, butterflies, arboreal invertebrates were more abundant and diverse 353 in miscanthus fields, because the latter were also more floristically diverse with respect of 354 weeds. Birds followed the same trend while small mammals showed no preference [16]. 355 However, for all investigated taxa the greatest number of species tended to concentrate in the 356 uncultivated field margins and, to a lesser degree, in openings. In contrast, on the crop itself, 357 the arthropod fauna was less diverse on the exotic miscanthus than on the native reed canary358 grass. It should be noted however that the study fields were not mature at the time of their 359 study ( $\leq 3$ years) and thus miscanthus did not reach canopy closure yet, on the contrary to reed 360 canary-grass. Whether the observed beneficial effect of miscanthus crops persist as the crop is 361 aging remains an unanswered question, but is very unlikely. Regarding plant species diversity, 362 very few data is available. Studies on plant diversity are complicated by the fact that only 1 to 
$36320 \%$ of the local species pool do actually express annually in cultivated fields [62].

364 Several studies revealed that plant biodiversity was greater in SRC plantations compared to 365 arable fields (see review by Rowe et al. [63]). This benefit persists over time, even after 366 several rotations. Most of the species recorded were common, ruderal herbs. However, the 367 direct introduction of shade-tolerant woodland species in the understories of SRC has been 368 successfully applied to increase plant biodiversity.

369 Positive effects of SRC on vertebrate (birds, mammals, amphibians, reptiles) and invertebrate 370 (coleoptera, butterflies, canopy insects) biodiversity compared to arable fields have also been 371 reported by various studies in Europe [63]. These positive effects have been primarily 372 attributed to the low chemical inputs compared to arable fields. For example, up to 19 more 373 bird species were recorded in SRC compared to arable and grassland controls [64]. SRC 374 benefits to woodland bird species, whilst species associated with open farmlands were rather 375 negatively impacted.

376 In SRC, biodiversity has been shown to depend on a host of factors, including stand age, 377 rotation length, crop type, stand size, and habitat connectivity [18]. For example, willow SRC 378 was found to benefit more to vertebrates and invertebrates than poplar SRC [63].

379 Almost no study provides an integrative view of the relationship between plant biodiversity 380 and the other trophic levels of the agro-ecosystem (with the exception of $[16,17]$ ), especially 381 phytophageous insects and their parasitoids/predators [65]. A notable exception is Huggett et 382 al. [66], who showed that some Aphids species, Rhopalosiphum padi and $R$. maidis, were able 383 to colonize miscanthus crops from other source crops, and inoculate a potentially harmful 384 virus.

385 A scarcely considered aspect is the potential increase in the introduction of invasive alien 386 species that bioenergy crops may cause $[57,67,68]$. This encompasses the potential to invade 
387 natural ecosystems of the crop species itself as well as its associated weed community.

388 Perennial grasses have many life history traits in common with invasive species, given they 389 are selected to tolerate poor quality habitats, rapid growth, high seed production, resistance to 390 pests, etc. [69, 70]. If non-invasiveness may be expected for the triploid, sterile Miscanthus $\mathrm{x}$ 391 giganteus (but see 71) other species like e.g. $M$. sinensis has already escaped from where it 392 was grown as an ornamental and became a harmful invader [71, 72]. Plant species that are to 393 be cultivated outside their native range, like miscanthus and switchgrass in Europe are at 394 potential risk of becoming invasive. However, even native plants if genetically modified 395 would pose a similar risk, as recently demonstrated with switchgrass in North America, since 396 physiologic and phenotypic changes led to alterations in plant-plant interactions and 397 ecological functions [73].

To conclude, the biodiversity impact of biofuel crops will depend on the species and 399 the former land use. The reduction in biodiversity caused by increased perennial crops will be 400 likely lower than that for first-generation biofuel production [74]. But their consequences to 401 biodiversity remain largely unstudied. Perennial crops can be beneficial to biodiversity when 402 appropriate crops are grown and sustainably managed in suitable areas, especially degraded or 403 eroded lands; or when they are planted as buffers around conventional annual crops since they 404 can provide habitats to various animals, and be used to filter nutrients or pollutants [75]. 405 Agricultural landscape heterogeneity may be a key, as at equal size, sites with high crop 406 diversity tend to have larger numbers of species than sites where only one type of crop is 407 grown [75, 76]. A landscape approach is thus required to consider the interacting factors at 408 play in the functioning of bioenergy agro-ecosystems, including the type and location of the 409 plant species to be grown, and farming and harvesting systems involved in their production. 410 Opportunities exist to develop systems that could provide net biodiversity benefits on the 411 short term (e.g. habitats for other species), but risks for long-term negative impacts (e.g. 
412 biological invasions by the crops or their associated biota) still need to be evaluated. This

413 should become easier as the number of these plantations in Europe increases.

414

\section{Integration into cropping systems}

\section{Why considering bioenergy crops within a cropping system?}

417 The cropping system is defined as "a set of management procedures applied to a given, 418 uniformly treated area, which may be a field, part of a field or a group of fields” [77]. These 419 procedures include the crop sequence and management for each crop within the sequence.

420 The introduction of bioenergy crops could generate several effects at cropping system level $421[78,79]$. These effects may be assessed through relevant performance criteria, which include 422 dry matter yield and quality (especially vis-a-vis the pre-treatment and conversion process), 423 energy balance, environmental impacts (such as GHG emissions, soil C dynamics, $\mathrm{N}$ losses 424 and water consumption), production costs and profitability. These criteria may be calculated 425 for a particular bioenergy crop but are strongly dependent on the cropping system it is 426 integrated into. For instance, the former land use (cropland, grassland or woodland) 427 determines whether energy crops are a net source or sink of GHG [3, 80].

428 Moreover, the management of bioenergy crops impacts the performance of the other crops 429 within the cropping system. For instance, the environment of the following crop may be 430 affected through the development of soil-borne pathogens or the availability of soil mineral $\mathrm{N}$, 431 with consequences on crop growth and yield [81]. In addition, long-term (or cumulative) 432 effects may also be observed on weed seed bank, soil structure [82] and SOC content, which 433 is likely to be affected by the withdrawal of cereal straw for bioenergy production [45]. 434 Repeated annual harvests of perennial crops in winter could damage soil structure and thus 435 limit the establishment and yields of the following crops [83]. 
437 Energy crops provide an opportunity to farmers to increase their crop portfolios and access 438 new markets, albeit with specific challenges. Introducing annual/pluriannual crops for 439 bioenergy production implies that cropping systems are only partly dedicated to bioenergy, as 440 other crops within the crop sequence may still be grown for food and feed production. 441 Moreover, such energy crops may be more easily introduced by farmers in usual crop 442 sequences, allowing (i) combined food and feed production on the same field (thus mitigating 443 the competition between food and non-food purposes), (ii) higher flexibility for farmers 444 compared to perennial crops, which are established for at least 15 years [25], and (iii) a 445 diversification of arable crop sequences with positive impacts on weed pressure [84], pest and 446 disease risks [85], soil fertility and structure, and yields [25 81]. However, annual 447 lignocelllulosic crops often have a higher reliance on chemical inputs than perennial crops [3, 448 8, 86]. Reducing this reliance implies a move towards agronomical low-inputs principles, 449 starting with a diversification of crops within the cropping system: (i) over the crop sequence, 450 (ii) within a growing season through species mixtures (possibly with mixed uses of the 451 different crops, i.e. food/feed and bioenergy; 67), and (iii) with the introduction of cover 452 crops.

453 In particular, the introduction of legumes and their conversion to energy deserves further 454 investigation [33]. Given their capacity to fix atmospheric N, legumes allow a significant 455 reduction of $\mathrm{N}$ fertilisation at the cropping system scale (no $\mathrm{N}$ fertilisation on a sole legume, 456 or reduced $\mathrm{N}$ fertilisation on a legume-other species intercropping, and reduced $\mathrm{N}$ fertilisation 457 on a crop following a legume). This reduces upstream GHG emissions due to fertilizer 458 manufacturing and field emissions of $\mathrm{N}_{2} \mathrm{O}$ resulting from fertilizer $\mathrm{N}$ applications, along with 459 the energy consumption of the cropping system [33, 88]. Other benefits were observed in 460 terms of ecosystem services, such as soil structure improvement, increase in C sequestration 
461 (due to higher soil organic $\mathrm{N}$ content) or lower nitrate leaching under pluriannual legumes 462 with deep root systems [33]. Given these advantages, legumes could play a role in the 463 production of biomass for bioenergy [33]. Valorisations for second-generation bioethanol 464 have already been investigated, based either on whole plants [87] or co-products (alfalfa 465 stems; 89). However, the use of sole legumes as energy crops incurs potential drawbacks such 466 as lower soil fertility in the case of whole-plant harvesting, lower yields compared to other 467 energy crops, and biomass quality constraints with respect to the conversion processes [87, 468 90, 91]). Intercropping legumes with other energy crops could be a way of achieving higher 469 yields and better quality, which remains to be investigated on a commercial scale. The choice 470 of species and cultivars as well as crop management are important issues, as well as the 471 impact of the introduction of such intercrops in cropping systems.

472 Other ways to reduce the use of chemical inputs while maintaining soil fertility may be 473 investigated. The recycling of harvest or process residues is of primary importance to improve 474 the overall sustainability of the bioenergy production from dedicated crops. For instance, part 475 of the straw produced by the cropping systems should be returned to soils to maintain their 476 SOC content. For that purpose, tools can be developed in order to determine the amount of 477 straws that can be exported without jeopardizing the organic quality of the soils (e.g. 45). 478 Moreover, the use of process residues from biomass pre-treatment and conversion processes 479 offer a particularly interesting avenue to substitute chemical fertilizers. More generally, the 480 use of urban wastes as fertilizers is probably easier on non-food crops than on food crops, 481 since contamination risks are less critical.

482 Compared to (pluri-)annual crops, the advantages of perennial crops are the production of 483 high amounts of biomass per hectare with low inputs, together with low environmental 484 impacts compared to arable crops (e.g., [3, 27]). However, some concerns should be raised, 485 for instance on the impacts after their cultivation (e.g. on GHG emissions, soil fertility and on 
486 the establishment of succeeding crops), or the location of these crops (current cropland vs. 487 other types of lands). The competition between food and energy crops provides an incentive 488 for establishing perennial lignocelllulosic crops on alternative lands (marginal lands, 489 including contaminated soils, fields that are far from the farm headquarters or difficult to 490 manage).

\section{Future research needs}

492 Various crop management systems have been compared for energy crops [3, 8, 89], but few 493 options have been investigated on the crop sequence itself (in which annual, multiannual and 494 perennial crops are included). Thus, further research is warranted to design and assess 495 innovative cropping systems including the range of candidate bioenergy crops, possibly 496 grown in alternative lands, and also in the face of future climate changes. As mentioned 497 earlier, bioenergy crops both include well-known crops (already grown by farmers for food or 498 feed purposes, such as cereals or legumes) and dedicated crops (usually newly introduced in a 499 given area, such as miscanthus, switchgrass or SRC).

500 The design of innovative cropping systems using expert knowledge [92] is a methodology 501 that could be appropriate to identify cropping systems including bioenergy crops due to the 502 fragmentary information available on food, feed and bioenergy crops (distributed among 503 experts), including their combined effects in a crop sequence. Experts could be local advisors 504 of extension services (to benefit from their knowledge on the crops currently grown in the 505 study area, either for food, feed or possibly bioenergy purposes) and scientists (more familiar 506 with dedicated bioenergy crops). Synthetizing the available information on bioenergy crops 507 which have already been grown in experimental conditions in several locations - through 508 meta-analysis (e.g., [93]) could help enhancing the expertise on bioenergy crops.

509 To implement an ex ante assessment of innovative cropping systems including bioenergy 
510 crops, future research is required on the rotational management of new annual/pluriannual 511 bioenergy crops [25], but also on the long-term effects of perennial crops such as miscanthus 512 on soil structure and SOC content and their subsequent effects of the following crops. In 513 addition, it would be necessary to investigate a wider range of crop management systems, soil 514 and weather contexts than currently documented in the literature. The references on bioenergy 515 crops have been indeed mainly established on field experiments in which limiting factors are 516 usually well controlled. On-farm assessment should be developed, and marginal lands for the 517 production of perennial energy crops should be investigated. Regarding the soil and weather 518 contexts, modelling (using dynamic crop-soil models) is a mean to explore new climatic 519 conditions, and to help identifying cropping systems suited to climate change scenarios. 520 Lastly, multi-criteria decision-aid methods such as MASC [94] could be useful to facilitate the 521 assessment of cropping systems including bioenergy crops.

\section{Upscaling from local to supply-area scale}

524 Taking into account the spatial distribution of bioenergy crops is paramount to assessing their 525 environmental impacts, to the biomass logistics and supply chains, or even the food versus 526 energy competition issue [95]. For example, assessing biodiversity impacts implies a 527 knowledge of both the spatial distribution pattern of these crops and the species' natural 528 habitats [96]. The same assumption can be made regarding impacts on water quantity and 529 quality [97].

530 The spatial allocation of bioenergy crops, as any other agricultural land-use change, is a 531 complex process driven by biophysical, economic and social factors (e.g.: soil type, land use 532 competition, social acceptability; [98]). The biophysical context (agro-pedo-climatic 533 conditions) first determines if and where a given crop specie can be grown together with its 
534 corresponding potential yield. As many crop species may be grown on the same tract of land, 535 resulting in a competition between crops, land-use allocation is theoretically determined by 536 the relative profitability of these crops (income minus production cost), assuming that prices 537 result from the balance between biomass supply and demand. However, as opposed to wheat 538 grains, biomass feedstock is an emerging commodity for which there is currently no real 539 market price. For lignocellulosic crops to be adopted by farmers, their farm-gate price should 540 cover at least their production cost plus the foregone revenues due to land-use substitution 541 what is termed “opportunity costs”. Stakeholders' characteristics and behavior (e.g. risk 542 aversion, social embeddedness), as well as technical and policy constraints at the plot, farm or 543 landscape levels (e.g., plot size and distance to the farm headquarters) should also be taken 544 into account to determine the availability of biomass. Lastly, on the demand side, the 545 biorefinery-gate cost includes at least transportation costs. All these factors have to be 546 accounted for, and determine the relative location of biomass crops and biorefineries, as well 547 as the feedstock supply mix and price.

548 Several studies assess the sustainability of biomass feesdstock supply from a full-scale 549 bioenergy plant to world-scale scenarios of bioenergy deployment. Based on a literature 550 review, we propose a framework to classify such studies and characterize their accuracy and 551 relevance to aid in designing sustainable biomass supply areas (Table 4). We mainly 552 categorized the studies based on their approaches in terms of agronomic, economic and 553 behaviour analyses, combined with the extent to which these approaches were spatially554 explicit.

555

556 First, some studies focus on the production potential of biomass without taking into account 557 an overall demand for feedstock (whether in quantity or price) or the economic context, nor 558 providing information on how to actually achieve this potential (Group 1). Most of these 
559 studies assess the potential area that could be dedicated to energy crops at national or global 560 levels. We considered these studies as global biomass supply assessment based only on 561 potential resources (land availability, soil types, topography, climatic conditions, fixed food 562 demand, production costs, etc...). Within this group, three different approaches may be 563 distinguished:

564 Group 1a regroups non-spatialized, non-economic approaches. They either highlight conflicts 565 between agricultural and energy policies [99] by comparing technically achievable production 566 levels to targets set by policies, or simply quantify a country or a group of countries biomass 567 production levels [100]. Approaches from the group 1a can be used to help figuring out global 568 issues independently from actual driving forces of the land use process. They also provide a 569 base to assess GHG emissions at large scales.

570 Group 1b regroups spatialized, non-economic approaches. They differ from group 1a by the 571 fact that they introduce spatial differentiation to assess biomass potential production levels. 572 Spatial differentiation can be done on a coarse (e.g., at country level, [101]) or very fine scale 573 (e.g., with a $2 \mathrm{~km}^{2}$ resolution, [102]) but ignores economic or sociological factors. Studies 574 from group $1 \mathrm{~b}$ can be used for the same purposes as those of group 1a. They are however 575 more accurate regarding biophysical constraints as the spatialization is often a way to 576 discriminate regions based on their biophysical potentials to produce biomass.

577 Group 1c regroups spatialized economic approaches. In addition to the biophysicial 578 production potential, they map the potential production level under a given production cost 579 (i.e. providing cost-supply curves which are not based on opportunity costs).

581 One drawback of the Group 1 studies is that they make strong assumptions to assess biomass 582 supply. One of their most common tenets is the "Food - Feed - Nature first” paradigm [103] 583 which considers that biomass will not be grown on areas dedicated to food and feed 
584 production, or natural reserves. It prevents the authors from addressing the issue of 585 competition between major land uses. Although excluding areas for energy feedstock 586 cultivation based on predefined rules could reflect future regulations, the reality shows that 587 competition between food and non-food crops does exist [104].

589 While Group 1 approaches may be used to anticipate the trends of bioenergy crops 590 development, assessing the actual location of these crops by taking into account economic 591 and/or sociological driving factors at a supply-area scale is also of great interest to address the 592 feasibility and sustainability of a local bioenergy project. In our classification, Group 2 593 approaches propose modeling frameworks to locate biomass crops and/or bioenergy 594 production plants as "driven” by economic or supply factors: a demand in quantity (either 595 tons of biomass or energy equivalent) or in price (either in $€ /$ ton or $€ / M J$ ). However, the 596 approach and the level of details vary greatly among the existing studies.

598 Group 2a studies assess biomass supply and farm-gate cost for given energy demand levels, 599 but without addressing the spatial location of the production. Approaches regrouped in Group $6002 \mathrm{~b}$ attempts to locate energy crops production so as to maximize their net energy supply, but 601 without accounting for the economic context and, thus, the feasibility of this production. 602 Conversely, Group 2c studies locate energy crops production based on more or less robust 603 economic criteria to meet a given demand. They can thus better assess the environmental 604 impacts of such a production due to land use change. Groups $2 \mathrm{~d}$ to $2 \mathrm{f}$ approaches go one step 605 further by including a biorefinery or a power plant- either in a predetermined or open location 606 or - and by addressing transportation costs. Whereas Group 2d approaches sometimes rely on 607 strong hypotheses concerning the type of land available for bioenergy crops (e.g. marginal or 608 low-yielding land, food first paradigm), Group 2e studies allow for competition between food 
609 and energy crops on agricultural land, thus being more realistic. Group $2 \mathrm{f}$ studies make the

610 first step towards better accounting for farmers and stakeholders behaviours by integrating

611 decision processes in their models (e.g.: using a rule based model in ref 105 or an agent-

612 based model in ref 106).

613

614 Regarding sustainability assessment, studies from group 2 seem more interesting as they 615 simulate more realistic scenarios of bioenergy production. Their accuracy towards the 616 assessment of future development of bioenergy crops increases as they take into account the 617 complexity of the processes involved. However, very few studies attempt to address this 618 complexity (only Group $2 \mathrm{f}$ does), most of them relying on hypotheses to circumvent it. 619 Taking into account this complexity involves several dimensions:

620 - biomass managers' choices to grow and locate bioenergy crops: most of the models 621 taking into account stakeholders' decision to grow energy crops yield the "optimal” 622 spatial distribution of energy crops based on farmers' profit maximization and also 623 often on transport cost minimization. As a matter of fact, the spatial distribution of 624 agricultural crops is determined by several factors: biophysical and economic ones 625 (that determine crops' relative competitiveness), but also technical and sociological 626 ones $[107,108]$. On the economic side, farmers are not mere profit maximizers. 627 Studies at a finer grain therefore have to take into account farmers' risk aversion as 628 well as the spatial configuration of farms, when it comes to the adoption of new crops 629 and especially perennials, which require a large upfront investment and provide 630 income only after a few years' time [109]. Moreover, these crops actually involve a 631 larger range of stakeholders since they can be grown by farmers but also by energy 632 producers or institutional stakeholders [110]. Modelling approaches should then be 633 refined regarding the decision processes of these stakeholders. 
634 - taking into account the diversity of production systems within the feedstock supply

635 area: biomass production systems are more diversified than with arable crops (e.g.:

636 farm based, industry based, collective management). To our knowledge, there is

637 currently no modeling framework dealing with this question. Thus, researchers should

638 seek to account for this diversity to develop sustainable biomass supply areas.

639 - taking into account the interlinkages between these systems to understand and predict

640 the development of feedstock supply areas: the diversity of crop production systems

641 induces a diversity of management scales (e.g. field, farm, industry supply area,

642 municipality; Figure 1), thus increasing the complexity of the biomass development

643 process $[111,112]$.

644

645 As appears in Table 3, existing modelling frameworks to assess energy crops spatial 646 development only partly address this complexity. Also, our knowledge of energy crops is 647 currently limited, whether in terms of empirical data or theoretical frameworks. In conclusion, 648 the availability of data related to bioenergy crops location, development and impacts should 649 be improved to validate theoretical modelling frameworks and to improve the sustainability 650 assessment of biomass supply.

651

\section{Social sustainability of bioenergy chains}

653 When compared to the other two pillars of sustainable development -environmental and 654 economic, the social assessment of bio-energy projects has been lagging behind initially. 655 However, over the last few years, the social dimension of bioenergy projects has received 656 increasing attention both from the general public and the scientific community. The social 657 implications of bio-based projects are important both in terms of public perception of the risks 
658 and opportunities of these projects, and of the technical and organizational innovations 659 necessary for their successful implementation $[27,113]$.

660 One of the challenges associated to conducting a comprehensive social sustainability 661 assessment of bioenergy chains is the geographical dispersion and heterogeneity of the 662 population potentially affected. Given the number of countries involved in the bioenergy 663 value chain -both in the developed and developing world, there exist multiple types of socio664 economic impacts depending on the legal framework, institutional arrangements, social norms 665 as well as socio-economic characteristics of the affected population. As a result, the potential 666 effects associated to the production and consumption of bio-energy products may be 667 considerably different in terms of the type of impact, relevance and/or its magnitude 668 depending on the considered region and, of course, the specificities of each step of the value669 chain analyzed. This fact represents a methodological challenge but successful initiatives have 670 emerged over the last few years which represent a considerable step forward in the right 671 direction $[114,115]$.

672 In developed countries, where the focus is on reviving economic growth and mitigating 673 climate change, bioenergy can stimulate a green recovery -generating more jobs and 674 stimulating the economy, diversify energy supply and abate greenhouse gas emissions [114]. 675 Nevertheless, given the economic crisis that is currently affecting Europe and most of the 676 word, the social acceptability of any bio-based project is very much related to its potential net 677 impact in terms of economic stimulus and job creation opportunities. In fact, the latter is one 678 of the reasons frequently cited for encouraging deployment of bioenergy systems, particularly 679 when projects take place in rural areas, with high levels of unemployment or depopulation 680 trends [116]. Compared to fossil fuels, the employment rate of biofuel production is much 681 higher [117]. To carefully assess these aspects, one must not only take into consideration the 682 direct impact on the local or global economy -that is the effects on those sectors directly 
683 affected by the bioenergy value chain-, but also the indirect effects -that is the impact on 684 those other sectors that supply goods and services to the other sector that are directly affected. 685

686 One of the most widely used methodologies to quantify the direct and indirect effects of 687 projects is the Input-Output methodology [118, 119]. The I-O methodology is considered 688 asNeuwahl F, Löschel A, Mongelli I, Delgado L (2008) Employment impacts of EU biofuels 689 policy: combining bottom-up technology information and sectoral market simulations in an 690 input-output framework. Ecological Economics, 68, 447-460. a tool to gather information in a 691 systematic way about the productive relations between the different sectors in any given 692 country or regional economy. Besides estimating the associated direct and indirect effects on 693 the economy and job creation, the I-O models are used to estimate the multiplying effect that 694 a certain investment generates in the economy. In order to apply this methodology, data 695 requirements include: direct costs associated to the studied new activity as well as the 696 National Input-Output table (or, if available, the regional Input-Output table) which reflects 697 the flows between the different sectors comprised in a certain economy and that are regularly 698 published by the National Statistics Institutes.

699

700 However, one must go beyond the pure quantitative figures and also consider, for example, 701 the qualitative attributes of such employment (for example: what is their qualification, 702 duration, gender, etc). Social Impact Assessments (SIA) have been often used to complement 703 the more quantitative results derived from an input-output model. Burdge [120] defines SIA 704 as the systematic appraisal of "impacts on the day-to-day quality of life or persons and 705 communities whose environment is affected by a proposed policy, plan, programme or 706 project”. Guidelines for SIA have been developed, among others, by the World Bank and the 707 International Association for Impact Assessment. The social (and socio-economic) impacts to 
708 be covered in an assessment and the way this should be done should be case and context

709 specific. Thereferore, there is no general consensus on which indicators to use and how to 710 assess social impacts of bioenergy projects with SIA.

711

712 Similarly, environmental impact assessment methods (such as environmental life cycle 713 assessments) have also been "streched" to incorporate social issues. In 2006, life-cycle 714 experts acknowledged the necessity to offer a complementary tool to assess products'social 715 life cycle aspects [121]. As a result of this, the Social Life Cycle Assessment (S-LCA) concept 716 emerged aiming at complementing the Environmental Life Cycle Assessment (E-LCA) and 717 the Life Cycle Costing (LCC) in contributing to the full assessment of goods and services 718 within the context of sustainable development (UNEP, 2008). The ultimate goal of a S-LCA 719 is to promote improvement of social conditions throughtout the life cycle of a product. S-LCA 720 is intended to assess product and production related social and- to some extent- economic 721 impacts using a life cycle perspective.

722

723 Qualitative research, combining perspectives from institutional theory, social anthropology 724 [122] and knowledge/innovation studies [123] may be used to examine these effects though 725 they have not yet been applied to bio-energy or bio-materials sectors. These approaches rely 726 on empirical investigations such as stakeholder analysis [124] or the so-called CIPP (Context, 727 Input, Processes and Products) approach [125] to analyse a value chain. In addition to 728 employment and economic stimuli, innovative capacity is an important dimension to assess. 729 How the innovative capacity is affected by the context, input processes and products of the 730 studied systems and how specific barriers and potentials may be identified and addressed to 731 increase the sustainability of the proposed solutions. Moreover, there exist other impacts 
732 related to quality of life (health, housing, education, safety), equity, diversity, social mixing

733 cohesion, participation and governance and maturity that need to be assessed.

734

735 Populations from developing countries may also be affected by the increasing use of modern 736 bioenergy. As an example, switching from traditional to modern bioenergy systems can reduce 737 death and disease from indoor air pollution, free women and children from collecting 738 fuelwood and reduce deforestation [126]. It can also cut dependence on imported fossil fuels, 739 improving countries' foreign exchange balances and energy security. Furthermore, bioenergy 740 can expand access to modern energy services and bring infrastructure as roads, 741 telecommunications, schools and health centres to poor rural areas. In such areas, bioenergy 742 can increase the income of small-scale farmers, alleviating poverty and decreasing the gap 743 between rich and poor. In urban centres, using biofuels in transport can improve air quality 744 [114]. On the other hand, large-scale bioenergy projects may be dominated by large 745 international companies leading to negative socioeconomic impacts especially on land tenure 746 issues. Unclear land rights and poorly regulated land acquisition may lead to depriving small 747 farmers of their properties [117]. Bioenergy can also contribute to increased or reduced food 748 security depending on policies, agricultural systems, markets, prices and income levels. There 749 is now an increased concern about negative effects of bioenergy through increased food prices 750 that can negatively affect food importing countries [117].

752 To address the challenge to simulatenously promote sustainable production and use of 753 bioenergy worldwide, international cooperation is essential for building capacity to implement 754 successful solutions. As an attempt to promote the wider prodution and use of modern 755 bionergy, the Global Bioenergy Sustainability Partnership (GBEP) proposed 24 indicators of 756 sustainability intended to inform policy-making and facilitate the sustainable development of 
757 bioenergy [114]. These indicators do not provide answers or correct values of sustainability 758 but rather present the right questions to ask in assessing the effect of modern bioenergy 759 production and use in meeting nationally defined goals of sustainable development (Figure 2).

760 With regards to the social pillar, GBEP considers that the themes that are most relevant are: (i) 761 price and supply of a national food basket, (ii) access to land, water and other natural 762 resources, (iii) labour conditions, (iv) rural and social development, (v) access to energy, (vi) 763 human health and (vii) safety (Figure 2).

764

765 In summary, the social implications of bioenergy projects are recognized as key aspects to 766 assure the sustainability of biomass based energy generation. However, the complexity of the 767 assessment of these social implications is high, and the proposed methodologies are still on 768 their development stage with applications still scarce.

\section{Consequences at global scales: direct and indirect land-use}

$$
\text { changes }
$$

771 At a global scale, displacing food crops with energy crops in Europe may result in net 772 emissions of GHG through changes in land-use worldwide. A higher demand for agricultural 773 commodities such as bioenergy feedstock leads to higher prices and larger incentives for 774 farmers to increase their output, possibly through the conversion of non-agricultural land. The 775 resulting land-use changes (LUC) may cause the release of the below- and above-ground 776 carbon into the atmosphere. LUC emissions are direct if they result from for conversions of 777 land for the production of biomass for bioenergy, and indirect if they are due to conversions to 778 other land uses that would not have occurred without the development of biofuels. These 779 emissions may negate the GHG benefits of substituting fossile energy sources with biomass 780 [44], and are currently widely debated. 
781 It is impossible in practice to isolate LUC effects of biofuels (in particular indirect ones)

782 based solely on historic observations because of the simultaneous influence of several factors 783 affecting market equilibrium. In order to isolate LUC effects of biofuels, it is thus necessary 784 to rely on models capable of comparing, ceteris paribus, ie simulations « with » and « without 785 » biofuel development. Available evaluations in the literature are based either on (partial or 786 general equilibrium) economic models, or more heuristic approaches (causal-descriptive, 787 consequential LCA). The latter have the advantage of relying on a fairly simple, transparent, 788 and normalized framework that can be easily connected to that of standard LCAs. However, 789 as they rely solely on a quantity-based framework, these approaches are not well adapted to 790 fully account for market adjustments and the related indirect LUC effects. By construction, 791 economic model are better equipped in this respect. Nevertheless, their structure does not 792 always permit a clear distinction between direct and indirect LUC effects. In addition, the 793 complexity of the required modeling often makes the communication of results based on these 794 models more difficult. LUC effects on GHG emissions may be synthetized by indicators that 795 reflect annualized LUC emissions per unit of energy produced by biofuels. dLUC, iLUC, and $796 \mathrm{~d}+\mathrm{iLUC}$ factors measure the direct, indirect, and total component of these emissions, 797 respectively.

798 A recent meta-analysis [127], based on a systematic search of available bibliographic 799 references and a detailed analysis of the 71 most relevant and exploitable studies on LUC 800 issues, revealed a following conclusions. First, accounting for LUC due to the development of 801 biofuels is likely to increase GHG emissions that can be attributed to biofuels. Almost $90 \%$ of 802 the collected evaluations conclude that the development of biofuels leads to (direct or 803 indirect) LUC that cause GHG emissions (positive d+iLUC factor). Secondly, for more than a 804 quarter of the collected evaluations, the sole effect of LUC leads to emissions that are greater 805 than that of the reference fossil fuel (83.8 $\mathrm{CO}_{2}$ eq. $\left.\mathrm{MJ}^{-1}\right)$. When including life-cycle GHG 
806 emissions due to feedstock production, transformation and distribution of biofuels, the total 807 emissions are greater than that of the reference fossil fuel for more than half of the collected 808 evaluations. Thirdly, the collected evaluations are characterized by a large variability of the $809 \mathrm{~d}+\mathrm{iLUC}$ factor both between and within studies. This large variability actually reflects the 810 diversity of approaches, definitions, and assumptions (relative to land-use changes, 811 representation of underlying market mechanisms, biofuel chains, etc.) adopted in the studies. 812 Significant differences occurred among feedstock types, biofuel types, supply regions and the 813 regions of origin for biofuel demand. For example, the gap between biodiesel and bioethanol 814 ranged from 22 to $27 \mathrm{~g} \mathrm{CO}_{2}$ eq. $\mathrm{MJ}^{-1}$ depending on the methodology used to approach LUC 815 effects.

816 Even there are far fewer references for first generation biofuels than for lignocellulosic 817 feedstocks, the emissions related to LUC are lower by a factor of 2 to 10 with the latter type 818 of feedstock [127]. As discussed in the 'Feedstock production' section of this paper, the 819 conversion of arable food crops to lignocellulosics results in lower $\mathrm{N}_{2} \mathrm{O}$ emissions and a 820 temporary sequestration of $\mathrm{C}$ in the soil, ie negative dLUC emissions. Indirect LUC effects 821 deserve further investigation with lignocellulosic feedstocks, but their burden is unlikely to 822 significantly offset the GHG benefits from substituting fossile energy with bioenergy, 823 especially if the feedstockis grown on marginal land [128].

\section{Conclusion and outlook}

826 Ensuring a reliable and sustainable supply of biomass to meet policy targets in Europe raises 827 considerable challenges both in terms of research and practical implementation. While the 828 limits of bioenergy chains based on food crops are clearly appearing [9], lignocelllulosic 829 crops will be a key component of future feedstock supply chains, complementing other 830 sources of biomass such as residues and waste streams. There is a potential for large-scale 
831 development of such species but there are still many unknowns in terms of yield potentials in 832 a wide range of soil and climate conditions, on marginal lands or in the face of climate 833 change. Based on current evidence, the performance of these crops appear promising but is 834 still uncertain. Further research on yield drivers, optimal management at crop or cropping 835 system level, spatial distribution and environmental impacts is therefore warranted to guide 836 the design of feedstock supply chains.

837 Non-technical issues on production costs, learning curve and adoption, and farmers' risk 838 aversion should also be taken on board in this process. The cooperation of scientists with 839 stakeholders (farms, chain operators, value-chain), local authorities and policy-makers should 840 be fostered to develop suitable tools (data bases, models, decision support systems) for the 841 design, assessment and management of bioenergy chains that are efficient at abating GHG 842 emissions, minimizing adverse environmental and social impacts and generating benefits for 843 local communitities.

844 


\section{References}

847 [1] Edenhofer O, Pichs-Madruga R, Sokona Y, Seyboth K, Matschoss P, Kadnert S al. IPCC 848 Special Report on Renewable Energy Sources and Climate Change Mitigation. Cambridge 849 University Press. Cambridge United Kingdom and New York, NY, USA; 2011.

850 [2] Chum H, Faaij APC, Moreira J, Berndes G, Dhamija P, Dong H et al. Bioenergy. In: 851 Edenhofer O, Pichs-Madruga R, Sokona Y, Seyboth K, Matschoss P, Kadnert S et al., editors. 852 IPCC Special Report on Renewable Energy Sources and Climate Change Mitigation, 853 Cambridge University Press, Cambridge, United Kingdom and New York, NY, USA; 2011.

854 [3] Don A, Osborne B, Hastings A, Skiba Ute, Carter MS, Drewer J et al. Land-use change to 855 bioenergy production in Europe: implications for the greenhouse gas balance and soil carbon. 856 Global Change Biology Bioenergy 2011;4,372-391.

857 [4] AEBIOM. Annual statistical report on the contribution of Biomass to the Energy System 858 in the EU 27. European Biomass Association, Brussels ; 2011.

859 [5] Karp A, Shield I. Bioenergy from plants and the sustainable yield challenge. New Phytol 860 2008;179:15-32.

861 [6] Robertson GP, Dale VH, Doering OC, Hamburg, SP, Melillo JM, Wander, MM et al. 862 Sustainable biofuels redux. Science 2008;322:49-50.

863 [7] von Blottnitz H, McCurran MA. A review of assessments conducted on bio-ethanol as a 864 transportation fuel from a net energy, greenhouse gas, and environmental life cycle 865 perspective. J. Cleaner Prod. 2007;15:607-19.

866 [8] Boehmel C, Lewandowski I, Claupein W. Comparing annual and perennial energy 867 cropping systems with different management intensities. Agricultural Systems 2008;96:224868236. 
869 [9] Searchinger T, Heimlich R, Houghton R, Dong F, Elobeid A, Fabiosa J et al. Use of U.S 870 crop land for biofuel increases Greenhouses gases through emissions from land use change. 871 Science 2008;319:1238-40.

872 [10] van Dam J, Junginger M, Faaij A, Jurgens I, Best G, Fritsche U. Overview of recent 873 developments in sustainable biomass certification. Biomass Bioenergy 2008;32:749-80.

874 [11] Crutzen PJ, Mosier AR, Smith KA, Winiwarter W. N2O release from agro-biofuel 875 production negates global warming reduction by replacing fossil fuels. Atm Chem Physics 876 2008;8:389-95.

877 [12] Prieur A. Environmental and socio-technico-economic analysis of bio-based value 878 chains. Final report of project PNRB-ANABIO (0501C0083). IFP EN, Rueil-Malmaison, 879 France (in french); 2008.

880 [13] Farrell AE, Plevin RJ, Turner BT, Jones AD, O’Hare M, van Kammen DM. Ethanol can 881 contribute to energy and environmental goals. Science 2006;31:506-508.

882 [14] Reinhardt G. Bio-energy for Europe. Which ones fit best? Final report EC contract 883 CT98-3832, IFEU, Heidelberg; 2000.

884 [15] Gabrielle B, Gagnaire N. Life-cycle assessment of straw use in bio-ethanol production: A 885 case study based on biophysical modelling. Biomass Bioenergy 2008;32:431-41.

886 [16] Semere T, Slater FM. Invertebrate populations in Miscanthus (Miscanthus x giganteus) 887 and reed canary-grass (Phalaris arundinacea) fields. Biomass Bioenergy 2007;31:30-9.

888 [17] Semere T, Slater FM. Ground flora, small mammal and bird species diversity in 889 Miscanthus (Miscanthus x giganteus) and reed canary-grass (Phalaris arundinacea) fields. 890 Biomass Bioenergy 2007;31:20-29.

891 [18] Gosselin M. Impact de la production intensive de biomasse sur la biodiversité dans les 
892 taillis à très courte rotation. In: Landmann G, Gosselin F, Bohême I (editors) Bio2, Biomasse 893 et biodiversité forestières; augmentation de l'utilisation de la biomasse forestière : 894 implications pour la biodiversité et les ressources naturelles. Paris, MEEDDM-Ecofor; 2009.

895 [19] Stein A, Riley J, Halberg N. Issues of scale for environmental indicators. Agric Ecosyst 896 Environ 2001;87:215-232.

897 [20] Galloway JN, Aber JD, Erisman JW, Seitzinger SP, Howarth RW, Cowling EB et al. The 898 Nitrogen Cascade. BioScience 2003;53:341-56.

899 [21] Batidzirai B, Smeets E, Faaij A. Harmonising bioenergy resource potentials. 900 Methodological lessons from review of state of the art bioenergy potential assessments. 901 Renew Sustain Energy Rev 2012;16:6598-630.

902 [22] Mayfield CA, Foster CD, Smith CT, Gan J, Fox S. Opportunities, barriers, and strategies 903 for forest bioenergy and bio-based product development in the Southern United States. 904 Biomass Bioenergy 2007;31:631-7.

905 [23] Lewandowski I, Scurlock JMO, Lindvall E, Christou M. The development and current 906 status of perennial rhizomatous grasses as energy crops in the US and Europe. Biomass 907 Bioenergy 2003;25:335-61.

908 [24] Sanderson MA, Adler PR. Perennial forages as second generation bioenergy crops. Int J 909 Molecular Sci 2008;9:768-88.

910 [25] Zegada-Lizarazu W, Monti A. Energy crops in rotation. A review. Biomass Bioenergy 911 2011;35:12-25.

912 [26] Lal R. Crop residues as soil amendments and feedstock for bioethanol production. Waste 913 Management 2008;28:747-58.

914 [27] Cadoux S, Briand S, Chabbert B, Besnard A, Félix I, Savouré ML et al. Biomass 
915 productivity of different energy crops under French conditions. Results of the " REGIX » 916 experimental network. In: Proceedings 18th European Biomass Conference \& Exhibition, 917 Lyon, France; 2010, p. 269-272.

918 [28] Cadoux S, Ferchaud F, Demay C, Boizard H, Machet J-M, Fourdinier E et al. 919 Implications of productivity and nutrient requirements of greenhouse gas balance of annual 920 and perennial bioenergy crops. GCB Bioenergy; in press.

921 [29] Scarlat N, Martinov M, Dallemand JF. Assessment of the availability of agricultural crop 922 residues in the European Union: Potential and limitations for bioenergy use. Waste Manag 923 2010;30:1889-97.

924 [30] Agreste. Enquête pratiques culturales 2006. Web-based data base : 925 http://agreste.maapar.lbn.fr/ReportFolders/ReportFolders.aspxCS_referer=\&CS_ChosenLang 926 =fr (last visited 2 April 2013), Ministère de l'agriculture, de l'agroalimentaire et de la forêt, 927 Paris.

928 [31] Cadoux S, Riche AB, Yates NE, Machet JM. Nutrient requirements of Miscanthus x 929 giganteus: Conclusions from a review of published studies. Biomass Bioenergy 2012;38:1493022.

931 [32] Monti A, Barbanti L, Zatta A, Zegada-Lizarazu W. The contribution of switchgrass in 932 reducing GHG emissions. GCB Bioenergy 2012;4:420-34.

933 [33] Jensen E, Peoples M, Boddey R, Gresshoff P, Hauggaard-Nielsen H, Alves B et al. 934 Legumes for mitigation of climate change and the provision of feedstock for biofuels and 935 biorefineries. A review. Agron Sustain Dev 2012;32:329-64.

936 [34] Cheney JH, Johnson KD, Volenec J, Greene DK. Biomass potential of selected grass and 937 legume crops. Energy Sources 1991;13:283-92.

938 [35] Lewandowski I, Kauter D. The influence of nitrogen fertilizer on the yield and 
939 combustion quality of whole grain crops for solid fuel use. Industrial Crops and Products 940 2003;17:103-17.

941 [36] Barbanti L, Grandi S, Vecchi A, Venturi G. Sweet and fibre sorghum ( Sorghum bicolor

942 (L.) Moench), energy crops in the frame of environmental protection from excessive nitrogen 943 loads. Eur J Agron 2006;25:30-9.

944 [37] Jorgensen JR, Deleuran LC, Wollenweber B. Prospects of whole grain crops of wheat, 945 rye and triticale under different fertilizer regimes for energy production. Biomass Bioenergy 946 2007;31:308-17.

947 [38] Brunet N, Debaeke P, Delos M, Guérin O, Guindé L, Mischler P et al. Ecophyto R\&E : 948 vers des systèmes de culture économes en intrants et en produits phytosanitaires. 2009; INRA, 949 Paris.

950 [39] Adler PR, Del Grosso SJ, Parton WJ. Life-cycle assessment of net greenhouse-gas flux 951 for bioenergy cropping systems. Ecolog Applications 2007;17:675-91.

952 [40] Jorgensen RN, Jorgensen BJ, Nielsen NE, Maag M, Lind AM. N2O emission from 953 energy crop fields of Miscanthus "Giganteus" and winter rye. Atmos Environ 1997;31:2899954904.

955 [41] Gauder M, Butterbach-Bahl K, Graeff-Hönninger S, Claupein W, Wiegel R. Soil-derived 956 trace gas fluxes from different energy crops - results from a field experiment in Southwest 957 Germany. GCB Bioenergy 2012;4:289-301.

958 [42] Behnke G, David M, Voigt T. Greenhouse Gas Emissions, Nitrate Leaching, and Biomass 959 Yields from Production of Miscanthus $\times$ giganteus in Illinois, USA. BioEnergy Research 960 2012;4:801-13.

961 [43] Schmer MR, Liebig MA, Hendrickson JR, Tanaka DL, Phillips RL. Growing season 962 greenhouse gas flux from switchgrass in the northern great plains. Biomass Bioenergy 
963 2012;45:315-19.

964 [44] Fargione J, Hill J, Tilman D, Polasky S, Hawthorne P. Land Clearing and the Biofuel 965 Carbon Debt. Science 2008;319:1235-7.

966 [45] Saffih-Hdadi K, Mary B. Modeling consequences of straw residues export on soil 967 organic carbon. Soil Biol Biochem 2008;40:594-607.

968 [46] Bessou C, Ferchaud F, Gabrielle B, Mary B. Biofuels, greenhouse gases and climate 969 change. A review. Agron Sustain Dev 2011;31:1-79.

970 [47] Beaudoin N, Saad JK, Van Laethem C, Machet JM, Maucorps J, Mary B. Nitrate 971 leaching in intensive agriculture in Northern France: Effect of farming practices, soils and 972 crop rotations. Agric Ecosyst Environ 2005;111:292-310.

973 [48] Beaudoin N, Denys D, Muller JC, Monbrun MD, Ledain C. Influence d'une culture de 974 luzerne sur le lessivage du nitrate dans les sols de Champagne crayeuse. Fourrages 975 1992;129:45-57.

976 [49] Vanloocke A, Bernacchi CJ, Twine TE. The impacts of Miscanthus x giganteus 977 production on the Midwest US hydrologic cycle. GCB Bioenergy 2010;2:180-91.

978 [50] Hickman GC, Vanloocke A, Dohleman FG, Bernacchi CJ. A comparison of canopy 979 evapotranspiration for maize and two perennial grasses identified as potential bioenergy 980 crops. GCB Bioenergy 2010;2:157-68.

981 [51] McIsaac GF, David MB, Mitchell CA. Miscanthus and switchgrass production in Central 982 Illinois: impacts on hydrology and inorganic nitrogen leaching. J Environ Qual 2010;39:17909839.

984 [52] Aronsson PG, Bergstrom LF. Nitrate leaching from lysimeter-grown short-rotation 985 willow coppice in relation to N-application, irrigation and soil type. Biomass Bioenergy 
986 2001;21:155-64.

987 [53] Christian DG, Riche AB. Nitrate leaching losses under Miscanthus grass planted on a 988 silty clay loam soil. Soil Use Manag 1998;14:131-35.

989 [54] Goodlass G, Green M, Hilton B, McDonough S. Nitrate leaching from short-rotation 990 coppice. Soil Use Manag 2007;23:178-84.

991 [55] Mortensen J, Nielsen KH, Jorgensen U. Nitrate leaching during establishment of willow 992 (Salix viminalis) on two soil types and at two fertilization levels. Biomass Bioenergy 993 1998;15,457-66.

994 [56] Schmidt-Walter P, Lamersdorf N. Biomass Production with Willow and Poplar Short 995 Rotation Coppices on Sensitive Areas-the Impact on Nitrate Leaching and Groundwater 996 Recharge in a Drinking Water Catchment near Hanover, Germany. BioEnergy Res 997 2012;5:546-62.

998 [57] Lewandowski I, Faaij A. Steps towards the development of a certification system for 999 sustainable biomass trade - analysis of existing approaches. Utrecht University. Utrecht, the 1000 Netherlands; 2004.

1001 [58] Koh LP, Ghazoul J. Biofuels, biodiversity, and people: understanding the conflicts and 1002 finding opportunities. Conservation Biol 2008;141:2450-60.

1003 [59] Danielsen F, Beukema H, Burgess ND, Parish F, Brühl CA, Donald PF et al. Biofuel 1004 plantations on forested lands: Double jeopardy for biodiversity and climate. Conservation 1005 Biol 2009;23:348-58.

1006 [60] Phalan B, Fitzherbert EB, Rafflegeau S, Struebig MJ, Verwilghen A. Conservation in Oil1007 Palm Landscapes. Conservation Biol 2009;23,244-5.

1008 [61] Hellmann F, Verburg PH. Impact assessment of the European biofuel directive on land 
1009 use and biodiversity. J Environ Manag 2010;91:1389-96.

1010 [62] Debaeke P. Dynamique de quelques dicotylédones adventices en culture de céréales. I. 1011 Relation flore levée-stock semencier. Weed Res 1998;28:251-63.

1012 [63] Rowe RL, Street NR, Taylor G. Identifying potential environmental impacts of large1013 scale deployment of dedicated bioenergy crops in the UK. Renew Sustain Energy Rev 1014 2007;13:271-90.

1015 [64] Sage RB, Cunningham M, Boatman N. Birds in willow short-rotation coppice compared 1016 to other arable crops in central England and a review of bird census data from energy crops in 1017 the UK. Ibis 2006;148:184-97.

1018 [65] Spencer JL, Raghu S. Refuge or Reservoir? The potential impacts of the biofuel crop 1019 Miscanthus x giganteus on a major pest of maize. PLoS ONE 2009;4:e8336.

1020 [66] Huggett DAJ, Leather SR, Walters KFA. Suitability of the biomass crop Miscanthus 1021 sinensis as a host for the aphids Rhopalosiphum padi (L.) and Rhopalosiphum maidis (F.), and 1022 its susceptibility to the plant luteovirus Barley Yellow Dwarf Virus. Agric Forest Entomol 1023 1999;1:143-9.

1024 [67] Chimera CG, Buddenhagen CE, Clifford PM. Biofuels: the risks and dangers of 1025 introducing invasive species. Biofuels 2010;1,785-96.

1026 [68] Genovesi P. European biofuel policies may increase biological invasions: the risk of 1027 inertia. Current Opinion Environ Sustain 2011;3:66-70.

1028 [69] Raghu S, Anderson RC, Daehler CC, Davis AS, Wiedenmann RN, Simberloff D et al. 1029 Adding Biofuels to the Invasive Species Fire? Science 2006;313:1742.

1030 [70] Barney JN, DiTomaso JM. Non-native species and bioenergy: are we cultivating the next 1031 invaders? BioScience 2008;58:64-70. 
1032 [71] Schnitzler A. Miscanthus: l'homme cultive-t-il un nouvel envahisseur? Agence de l'Eau 1033 Rhin-Meuse, Université de Metz Paul Verlaine, 41p.;2011.

1034 [72] Jörgensen U. Benefits versus risks of growing biofuel crops: the case of Miscanthus. 1035 Current Opinion Environ Sustain 2011;3:24-30.

1036 [73] DiTomaso JM, Barney JN, Fox AM. Biofuel Feedstocks: The Risk of Future Invasions. 1037 All U.S. Government Documents (Utah Regional Depository). Paper 79;2007. 1038 http://digitalcommons.usu.edu/govdocs/79

1039 [74] Fletcher Jr RJ, Robertson BA, Evans J, Doran PJ, Alavalapati JRR, Schemske DW. 1040 Biodiversity conservation in the era of biofuels: risks and opportunities. Frontiers Ecol 1041 Environ 2010;9:161-8.

1042 [75] Dale VH, Kline KL, Wiens J, Fargione J. Biofuels: implications for land use and 1043 biodiversity. Biofuels and Sustainability Reports. The Ecological Society of America, 1044 Washington DC; 2010. www.esa.org/biofuelsreports

1045 [76] Benton TG, Vickery JA, Wilson JD. Farmland biodiversity: is habitat heterogeneity the 1046 key? Trends Ecol Evol 2003;18:182-8.

1047 [77] Sébillote M. Systèmes de culture, un concept opératoire pour les agronomes. In: Combe 1048 L, Picard D, editors. Les Systèmes De Culture, INRA, Paris; 1990, p. 165-196.

1049 [78] Karlen DL, Varvel GE, Bullock DG, Cruse M. Crop rotations for the 21st century. 1050 Advances Agron 1994;53:1-45.

1051 [79] Robson MC, Fowler SM, Lampkin NH, Leifert C, Leitch M, Robinson D et al. The 1052 agronomic and economic potential of break crops for ley/arable rotations in temperate organic 1053 agriculture. Advances Agron 2002;77:369-427.

1054 [80] Saint Clair S, Hillier J, Smith P. Estimating the pre-harvest greenhouse gas costs of 
1055 energy crop production. Biomass Bioenergy 2008;32:442-52.

1056 [81] Bennett AJ, Bending GD, Chandler D, Hilton S. Meeting the demand for crop 1057 production: the challenge of yield decline in crops grown in short rotations. Biological Rev 1058 2012;87:52-71.

1059 [82] Ball BC, Bingham I, Rees RM, Watson CA, Litterick A. The role of crop rotations in 1060 determining soil structure and crop growth conditions. Canadian J Soil Sci 2005;85:557-77.

1061 [83] Dufossé K, Drewer J, Gabrielle B, Drouet J-L. Soil carbon and N2O emission dynamics 1062 after destruction of a 20-year old Miscanthus stand, and comparison with a plot under annual 1063 crops. In: Proceedings 20th European Biomass Conference and Exhibition, 20-23 June 2012, 1064 Milan; 2012.

1065 [84] Deytieux V, Nemecek T, Knuchel RF, Gaillard G, Munier-Jolain NM. Is Integrated Weed 1066 Management efficient for reducing environmental impacts of cropping systems? A case study 1067 based on life cycle assessment. Eur J Agron 2012;36:11.

1068 [85] Colbach N, Lucas P, Cavelier N. Influence des successions culturales sur les maladies du 1069 pied et des racines du blé d’hiver. Agronomie 1994;14,525-40.

1070 [86] Hill J. Environmental costs and benefits of transportation biofuel production from food1071 and lignocellulose-based energy crops. A review. Agron Sustain Dev 2007;27:1-12.

1072 [87] Thomsen MH, Hauggaard-Nielsen H. Sustainable bioethanol production combining 1073 biorefinery principles using combined raw materials from wheat undersown with clover-grass. 1074 J Industrial Microbiol Biotech 2008;35:303-11.

1075 [88] Nemecek T, von Richthofen JS, Dubois G, Casta P, Charles R, Pahl H. Environmental 1076 impacts of introducing grain legumes into European crop rotations. Eur J Agron 2008;28:380107793. 
1078 [89] Lamb J, Jung H, Sheaffer C, Samac D. Alfalfa leaf protein and stem cell wall 1079 polysaccharide yields under hay and biomass management systems. Crop Sci 2007;47:1407108015.

1081 [90] Petersson A, Thomsen MH, Hauggaard-Nielsen H, Thomsen AB. Potential bioethanol 1082 and biogas production using lignocellulosic biomass from winter rye, oilseed rape and faba 1083 bean. Biomass Bioenergy 2007;31:812-9.

1084 [91] Martin C, Thomsen MH, Hauggaard-Nielsen H, Thomsen AB. Wet oxidation 1085 pretreatment, enzymatic hydrolysis and simultaneous saccharification and fermentation of 1086 clover-ryegrass mixtures. Bioresour Technol 2008;99:8777-82.

1087 [92] Lançon J, Wery J, Rapidel B, Angokaye M, Gerardeaux E, Gaborel C. An improved 1088 methodology for integrated crop management systems. Agron Sustain Dev 2007;27:101-10.

1089 [93] Miguez FE, Villamil MB, Long SP, Bollero G. Meta-analysis of the effects of 1090 management factors on Miscanthus $\times$ giganteus growth and biomass production. Agric Forest 1091 Meteorol 2008;148:1280-92.

1092 [94] Sadok W, Angevin F, Bergez JE, Bockstaller C, Colomb B, Guichard L. MASC: a 1093 qualitative multi-attribute decision model for ex ante assessment of the sustainability of 1094 cropping systems. Agron Sustain Dev 2009;29:447-61.

1095 [95] Blaschke T, Biberacher M, Gadocha S, Zocher D, Mittlböck M, Haslauer E et al. Virtual 1096 Power Plants: Spatial Energy Models in Times of Climate Change. In: Ehlers M, Behncke K, 1097 Gerstengarbe F-W, Hillen F, Koppers L, Stroink L et al. editors, Digital Earth Summit on 1098 Geoinformatics. Potsdam, Germany. Deutsch Nationalbibliothek, Wichmann Heidelberg; 1099 2008, p. 61-7.

1100 [96] Hellmann F, Verburg P. Spatially explicit modelling of biofuel crops in Europe. Biomass 1101 Bioenergy 2011;35,2411-24. 
1102 [97] Vereecken H, Kasteel R, Vanderborght J, Harter T. Upscaling hydraulic properties and 1103 soil water flow processes in heterogeneous soils: a review. Vadose Zone J 2007;6:1-28.

1104 [98] Turner II BL, Lambin EF, Reenberg A. The emergence of land change science for global 1105 environmental change and sustainabiltiy. Proc Natl Acad Sci USA 2007;104:20666-71.

1106 [99] Simon S, Wiegmann K. Modelling sustainable bioenergy potentials from agriculture for 1107 Germany and Eastern European countries. Biomass Bioenergy 2009;33:603-9.

1108 [100] Farine DR, O'Connell DA, John Raison R, May BM, O'Connor MH, Crawford FD et al. 1109 An assessment of biomass for bioelectricity and biofuel, and for greenhouse gas emission 1110 reduction in Australia. GCB Bioenergy 2012;4:148-75.

1111 [101] Campbell JE, Lobell DB, Genova RC, Field CB. The global potential of bioenergy on 1112 abandoned agriculture lands. Environ Sci Technol 2008;42:5791-94.

1113 [102] Lovett AA, Sunnenberg GM, Richter GM, Dailey AG, Riche AB, Karp A. Land Use 1114 Implications of Increased Biomass Production Identified by GIS-Based Suitability and Yield 1115 Mapping for Miscanthus in England. Bioenergy Res 2009;2:17-28.

1116 [103] Fischer G, Prieler S, van Velthuizen H, Berndes G, Faaij A, Londo M et al. Biofuel 1117 production potentials in Europe: Sustainable use of cultivated land and pastures, Part II: Land 1118 use scenarios. Biomass Bioenergy 2010;34:173-87.

1119 [104] UNCTAD. Price Formation in Financialized Commodity Markets: The Role of 1120 Information. Study prepared by the secretariat of UNCTAD, UNCTAD/GDS/2011/1, New 1121 York and Geneva; 2011.

1122 [105] Gaucherel C, Griffon S, Misson L, Houet T. Combining process-based models for 1123 future biomass assessment at landscape scale. Landscape Ecol 2010;25:201-15.

1124 [106] Scheffran J, BenDor T. Bioenergy and land use: a spatial-agent dynamic model of 
1125 energy crop production in Illinois. Int J Environ Pollution 2009;39:4-27.

1126 [107] Rindfuss RR, Walsh SJ, Turner BL, Fox J, Mishra V (2004) Developing a science of 1127 land change: Challenges and methodological issues. Proc Natl Acad Sci USA 1128 2004;101:13976-81.

1129 [108] Valbuena D, Verburg PH, Bregt AK, Ligtenberg A. An agent-based approach to model 1130 land-use change at a regional scale. Landscape Ecol 2010;25:185-99.

1131 [109] Bocquého G, Jacquet F. The adoption of switchgrass and miscanthus by farmers: Impact 1132 of liquidity constraints and risk preferences. Energy Policy 2010;38:2598-2607.

1133 [110] McCormick K, Käberger T. Key barriers for bioenergy in Europe: Economic conditions, 1134 know-how and institutional capacity, and supply chain co-ordination. Biomass Bioenergy 1135 2007;31:443-52.

1136 [111] Cooper J, Braster M, Woolsey E. Overview of the Chariton Valley switchgrass project: a 1137 part of the biomass power for rural development initiative. Proceedings of the conference 1138 BioEnergy '98: Expanding Partnerships. Madison, WI; 1998.

1139 [112] Madlener R. Innovation diffusion, public policy, and local initiative: The case of wood1140 fuelled district heating systems in Austria. Energy Policy 2007;35:1992-2008.

1141 [113] Adams P, Hammond G, McManus M, Mezzullo W. Barriers to and drivers for UK 1142 bioenergy development. Renew Sustain Energy Rev 2011;15:1217-27.

1143 [114] GBEP 2011. The Global Bioenergy Partnership Sustainability Indicators for Bioenergy. 1144 First Edition. ISBN 978-92-5-1072493.

1145 http://www.globalbioenergy.org/fileadmin/user_upload/gbep/docs/Indicators/The_GBEP_Sust 1146 ainability_Indicators_for_Bioenergy_FINAL.pdf

1147 (last visited: 2 April 2013) 
1148 [115] UNEP. Guidelines for Social Life Cycle Assessment Products. UNEP-SETAC Life1149 Cycle Initiative. Nairobi, Kenya; 2009.

1150 [116] Thornley P, Rogers J, Huang Y. Quantification of employment from biomas power 1151 plants. Renew Energy 2008;33:1922-7.

1152 [117] Rutz D, Janssen R. Socioeconomic Impacts of different scales of biofuel production in 1153 Africa. In: Rutz D, Janssen, R, editors. Bioenergy for Sustainable Development in Africa. 1154 Springer Dordrecht Heidelberg London New York; 2012.

1155 [118] Ten Raa, T. The Economics of Input-Output Analysis, Cambridge University Press, 1156 Cambridge; 2005.

1157 [119] Neuwahl F, Löschel A, Mongelli I, Delgado L. Employment impacts of EU biofuels 1158 policy: combining bottom-up technology information and sectoral market simulations in an 1159 input-output framework. Ecol Econ 2008;68:447-60.

1160 [120] Burdge R. The concepts, process and methods of SIA. The Social Ecology Press, 1161 Middleton, WI; 2004.

1162 [121] Griesshammer R, Benoît C, Dreyer LC, Flysjö A, Manhart A, Mazijn Bet al. Feasibility 1163 Study: Integration of social aspects into LCA. Discussion paper from UNEP-SETAC Task 1164 Force Integration of Social Aspects in LCA meetings in Bologna (January 2005), Lille (May 1165 2005) and Brussels (November 2005), Freiburg, Germany; 2006.

1166 [122] Crate SA. Cows, Kin and Globalization: An Ethnography of Sustainability. Altamira 1167 Press, Plymouth, UK; 2006.

1168 [123] Orlikowski W. Knowing in Practice: Enacting a collective capability in distributed 1169 organizing. Organization Sci 2002;13:249-73.

1170 [124] Mathur VN, Price ADF, Austin S. Conceptualising stakeholder engagement in the 
1171 context of sustainability and the assessment process. Construc Manag Econ 2008;26,601-9.

1172 [125] Matsaert H. Institutional analysis in natural resources research. Natural Resources 1173 Institute, University of Greenwhich; 2002.

1174 [126] ESF. Biomasa y desarrollo. Oportunidades de la biomasa para mejorar el acceso local a 1175 la energía en comunidades aisladas de América Latina, Fundacion Energia sin Fronteras, 1176 Madrid ; 2012.

1177 [127] De Cara S, Goussebaïle A, Grateau R, Levert F, Quinemer J, Vermont B. Critical review 1178 of studies evaluating the effect of land-use changes on the environmental balances of biofuels. 1179 Environment and Energy Agency (ADEME), Angers, France; 2012 (in French).

1180 [128] Havlık P, Schneider UA, Schmid E, Böttcher H, Fritz S, Skalský R et al. Global land1181 use implications of first and second generation biofuel targets. Energy Policy 2010;39:569011825702.

1183 [129] Aylott MJ, Casella E, Tubby I, Street NR, Smith P, Taylor G. Yield and spatial supply of 1184 bioenergy poplar and willow short-rotation coppice in the UK. New Phytol 2008;178:358-70.

1185 [130] Kern J, Hellebrand HJ, Scholz V, Linke B. Assessment of nitrogen fertilization for the $1186 \mathrm{CO}(2)$ balance during the production of poplar and rye. Renew Sustain Energy Rev 1187 2010;14:1453-60.

1188 [131] Heaton E, Voigt T, Long SP. A quantitative review comparing the yields of two 1189 candidate C 4 perennial biomass crops in relation to nitrogen, temperature and water. Biomass 1190 Bioenergy 2004;27:21-30.

1191 [132] Tilvikienè V., Kadžiulienè Ž., Dabkevičius Z. The evaluation of tall fescue, coksfoot 1192 and reed canary grass as energy crops for biogas production. Grassland Sci Eur 2010;15:30411936. 
1194 [133] Scholz V, Ellerbrock R. The growth productivity, and environmental impact of the 1195 cultivation of energy crops on sandy soil in Germany. Biomass Bioenergy 2002;23:81-92.

1196 [134] Habyarimana E, Laureti D, Ninno MD, Lorenzoni C. Performances of biomass sorghum 1197 [Sorghum bicolor (L.) Moench] under different water regimes in Mediterranean region. Indus 1198 Crops Prod 2004;20:23-28.

1199 [135] Sakellariou-Makrantonaki MS, Papanikolaou CD, Mygdakos E. Fiber sorghum biomass 1200 yield, water use efficiency and economic results under different levels of water using 1201 subsurface and surface irrigation systems. Fresenius Environ Bull 2009;18:1624-31.

1202 [136] Banowetz GM, Griffith SM, Steiner JJ, Ei-Nashaar HM. Mineral accumulation by 1203 perennial grasses in a high-rainfall environment. Energy Fuels 2009;23:984-8.

1204 [137] Beaudoin N, Saad JK, Van Laethem C, Machet JM, Maucorps J, Mary B. Nitrate 1205 leaching in intensive agriculture in Northern France: Effect of farming practices, soils and 1206 crop rotations. Agric Ecosyst Environ 2005;111:292-310.

1207 [138] Christian DG, Riche AB, Yates NE. The yield and composition of switchgrass and 1208 coastal panic grass grown as a biofuel in Southern England. Bioresour Technol 2002;83:115120924.

1210 [139] Comifer. Teneurs en P, K et Mg des organes végétaux récoltés. COMIFER, La Défense, 1211 France; 2007.

1212 [140] Da Silva Perez D, Briand S, Leygue J, Laboubée C, Chabbert B, Labalette F et al. 1213 Comparison of agricultural and forest biomass with the regard to biological processes fo 1214 bioethanol production of second generation. In: Proceedings 18th European Biomass 1215 Conference \& Exhibition, Lyon, France; 2010, p. 506-510.

1216 [141] Dien BS, Jung HJG, Vogel KP, Casler MD, Lamb JFS, Iten L et al. Chemical 1217 composition and response to dilute-acid pretreatment and enzymatic saccharification of 
1218 alfalfa, reed canarygrass, and switchgrass. Biomass Bioenergy 2006;30:880-91.

1219 [142] El-Nashaar HM, Banowetz GM, Peterson CJ, Griffith SM. Genetic variability of 1220 elemental concentration in winter wheat straw. Energy Fuels 2010;24:2020-7.

1221 [143] Energy Research Centre of the Netherlands. PHYLLIS, the composition of biomass and 1222 waste. Web-based data base: http://www.ecn.nl/phyllis2 (last visited 2 April 2013). ECN1223 Biomass, Petten, NL; 2012.

1224 [144] Gallejones P, Castellon A, Del Prado A, Unamunzaga O, Aizpurua A. Nitrogen and 1225 sulphur fertilization effect on leaching losses, nutrient balance and plant quality in a wheat1226 rapeseed rotation under a humid Mediterranean climate. Nutr Cycl Agroecosyst 2012;93:337122755.

1228 [145] Heckman JR, Sims JT, Beegle DB, Coale FJ, Herbert S, Bruulsema TW et al. Nutrient 1229 removal by corn grain harvest. Agron J 2003;95:587-91.

1230 [146] Jenkins BM, Baxter LL, Miles Jr TR, Miles TR. Combustion properties of biomass. 1231 Fuel Process Technol 1998;54:17-46.

1232 [147] Johnson JMF, Wilhelm WW, Karlen DL, Archer DW, Wienhold B, Lightle DT et al. 1233 Nutrient Removal as a Function of Corn Stover Cutting Height and Cob Harvest. BioEnergy 1234 Research 2010;3:342-52.

1235 [148] Kanapeckas J, Lemeziene N, Butkute B, Stukonis V. Evaluation of tall fescue ( Festuca 1236 arundinacea Schreb.) varieties and wild ecotypes as feedstock for biogas production. 1237 Zemdirbyste (Agriculture) 2011;98:149-56.

1238 [149] Kauter D, Lewandowski I, Claupein W. Quantity and quality of harvestable biomass 1239 from Populus short rotation coppice for solid fuel use-a review of the physiological basis 1240 and management influences. Biomass \& Bioenergy 2003;24:411-27. 
1241 [150] Lavado RS, Porcelli CA, Alvarez R. Nutrient and heavy metal concentration and 1242 distribution in corn, soybean and wheat as affected by different tillage systems in the 1243 Argentine Pampas. Soil Till Res 2001;62:55-60.

1244 [151] Ledin S. Willow wood properties, production and economy. Biomass \& Bioenergy 1245 1996;11:75-83.

1246 [152] Lemus R, Brummer EC, Moore KJ, Molstad NE, Burras CL, Barker MF. Biomass yield 1247 and quality of 20 switchgrass populations in southern Iowa, USA. Biomass \& Bioenergy 1248 2002;23:433-42.

1249 [153] Lloveras J, Ferran J, Boixadera J, Bonet J. Potassium fertilization effects on alfalfa in a 1250 Mediterranean climate. Agron J 2001;93:139-43.

1251 [154] Propheter JL, Staggenborg SA, Wu X, Wang D. Performance of annual and perennial 1252 biofuel crops: yield during the first two years. Agronomy J 2010;102:806-14.

1253 [155] Setiyono TD, Walters DT, Cassman KG, Witt C, Dobermann A. Estimating maize 1254 nutrient uptake requirements. Field Crops Research 2010;118:158-68.

1255 [156] Sweeney DW, Moyer JL, Havlin JL. Multinutrient fertilization and placement to 1256 improve yield and nutrient concentration of tall fescue. Agron J 1996;88:982-6.

1257 [157] Tharakan PJ, Volk TA, Abrahamson LP, White EH. Energy feedstock characteristics of 1258 willow and hybrid poplar clones at harvest age. Biomass \& Bioenergy 2003;25:571-80.

1259 [158] Thomason WE, Raun WR, Johnson GV, Taliaferro CM, Freeman KW, Wynn K et al. 1260 Switchgrass response to harvest frequency and time and rate of applied nitrogen. J Plant Nutr, 1261 2004;27:1199-1226.

1262 [159] US Department of Energy. Biomass Feedstock Composition and Property Database. 1263 Web-based data base: http://www.afdc.energy.gov/biomass/progs/search1.cgi (last visited 25 
1264 April 2013); 2004.

1265 [160] Vassilev SV, Baxter D, Andersen LK, Vassileva CG. An overview of the chemical 1266 composition of biomass. Fuel 2010;89:913-33.

1267 [161] Vos J, Van Der Putten PEL. Nutrient cycling in a cropping system with potato, spring 1268 wheat, sugar beet, oats and nitrogen catch crops. I. Input and offtake of nitrogen, phosphorus 1269 and potassium. Nutr Cycl Agroecosyst 2000;56:87-97.

1270 [162] Ericsson K, Nilsson LJ. Assessment of the potential biomass supply in Europe using a 1271 resource-focused approach. Biomass Bioenergy 2006;30:1-15.

1272 [163] Haughton AJ, Bond AJ, Lovett AA, Dockerty T, Sünnenberg G, Clark SJ et al. A novel, 1273 integrated approach to assessing social, economic and environmental implications of changing 1274 rural land-use: a case study of perennial biomass crops. J Applied Ecol 2009;46:315-22.

1275 [164] Sudha P, Ravindranath NH. Land availability and biomass production potential in India. 1276 Biomass and Bioenergy 1999;16:207-21.

1277 [165] Fischer G, Prieler S, van Velthuizen H, Lensink SM, Londo M, de Wit M. Biofuel 1278 production potentials in Europe: Sustainable use of cultivated land and pastures. Part I: Land 1279 productivity potentials. Biomass Bioenergy 2010;34:159-72.

1280 [166] Jager HI, Baskaran LM, Brandt CC, Davis EB, Gunderson CA, Wullschleger SD. 1281 Empirical geographic modeling of switchgrass yields in the United States. GCB Bioenergy 1282 2010;2:248-57.

1283 [167] Piketty MG, Wichert M, Fallot A, Aimola L. Assessing land availability to produce 1284 biomass for energy: The case of Brazilian charcoal for steel making. Biomass and Bioenergy 1285 2009;33:180-90.

1286 [168] Smeets EMW, Faaij APC, Lewandowski IM, Turkenburg WC. A bottom-up assessment 
1287 and review of global bio-energy potentials to 2050. Progr Energy Combustion Sci 2007;33: 1288 56-106.

1289 [169] De Wit M, Faaij A. European biomass resource potential and costs. Biomass and 1290 Bioenergy 2010;34:188-202.

1291 [170] Ballarin A,Vecchiato D, Tempesta T, Marangon F, Troiano S. Biomass energy 1292 production in agriculture: A weighted goalprogramming analysis. Energy Policy 1293 2011;39:1123-31.

1294 [171] Callesen I, Grohnheit PE, Ostergard H. Optimization of bioenergy yield from cultivated 1295 land in Denmark. Biomass and Bioenergy 2010;34:1348-62.

1296 [172] Fiorese G, Guariso G. A GIS-based approach to evaluate biomass potential from energy 1297 crops at regional scale. Environ Model Software 2010;25:702-11.

1298 [173] Tenerelli A, Carver S. Multi-criteria, multi-objective and uncertainty analysis for agro1299 energy spatial modelling. Applied Geog 2012;32:724-36.

1300 [174] De La Torre Ugarte DG, Ray DE. Biomass and bioenergy applications of the POLYSYS 1301 modeling framework. Biomass and Bioenergy 2000;18:291-308.

1302 [175] Geyer R, Stoms DM, Lindner JP, Davis FW, Wittstock B. Coupling GIS and LCA for 1303 biodiversity assessments of land use. Int J Life Cycle Assessment 2010;15:454-67.

1304 [176] Hellwinckel CM, West TO, De La Torre Ugarte DG, Perlack RD. Evaluating possible 1305 cap and trade legislation on cellulosic feedstock availability. GCB Bioenergy 2010;2:278-87.

1306 [177] Krasuska E, Cadorniga C, Tenorio JL, Testa G, Scordia D. Potential land availability for 1307 energy crops production in Europe. Biofuels Bioproducts Biorefining-Biofpr 2010;4,658-73.

1308 [178] Forster M, Helms Y, Herberg A, Köppen A, Kunzmann K, Radtke D et al. A site-related 1309 suitability analysis for the production of biomass as a contribution to sustainable regional 
1310 land-use. Environ Manag 2008;41:584-98.

1311 [179] Shi X, Elmore A, Li X, Gorence NJ, Jin H, Zhang X et al. Using spatial information 1312 technologies to select sites for biomass power plants: A case study in Guangdong Province, 1313 China. Biomass Bioenergy 2008;32:35-43.

1314 [180] van der Hilst F, Dornburg V, Sanders JPM, Elbersen B, Graves A, Turkenburg WC et al. 1315 Potential, spatial distribution and economic performance of regional biomass chains: The 1316 North of the Netherlands as example. Agric Syst 2010;103:403-17.

1317 [181] Tittmann PW, Parker, NC, Hart QJ, Jenkins BM. A spatially explicit techno-economic 1318 model of bioenergy and biofuels production in California. J Transport Geog 2010;18:715-28.

1319 [182] Bryan BA, Ward J, Hobbs T. An assessment of the economic and environmental 1320 potential of biomass production in an agricultural region. Land Use Policy 2008;25:533-49.

1321 [183] Egbendewe-Mondzozo A, Swinton SM, Izaurralde CR, Manowitz DH, Zhang X. 1322 Biomass supply from alternative cellulosic crops and crop residues: A spatially explicit 1323 bioeconomic modeling approach. Biomass Bioenergy 2011;35:4636-47.

1324 [184] Bauen AW, Dunnett AJ, Richter GM, Dailey AG, Aylott M, Casella E et al. Modelling 1325 supply and demand of bioenergy from short rotation coppice and Miscanthus in the UK. 1326 Bioresource Technology 2010 ;101:8132-43.

1327 [185] ADEME. Life cycle assessments applied to first generation biofuels used in France. 1328 Environment and Energy Agency (ADEME), Angers, France ; 2010 (in French).

1329 [186] Amaducci S, Amaducci MT, Benati R, Venturi G. Crop yield and quality parameters of 1330 four annual fibre crops (hemp, kenaf, maize and sorghum) in the North of Italy. Industrial 1331 Crops and Products 2000;11:179-86.

1332 [187] Guidi W, Tozzini C, Bonari E. Estimation of chemical traits in poplar short-rotation 
1333 coppice at stand level. Biomass Bioenergy 2009;33:1703-09.

1334 [188] Lee D, Owens VN, Boe A, Jeranyama P. Composition of Herbaceous Biomass 1335 Feedstocks. South Dakota State University, Brookings ; 2007.

1336 [189] Stolarski MJ, Szczukowski S, Tworkowski J, Wroblewska H, Krzyzaniak M. Short 1337 rotation willow coppice biomass as an industrial and energy feedstock. Industrial Crops and 1338 Products 2011;33:217-23.

1339

1340

1341

1342

1343

1344

1345

1346

1347 


\section{Figure captions}

1349

1350 Figure 1: Drivers and performance criteria for bioenergy value chains, from plot to global 1351 scales . Blue boxes $=$ drivers; orange boxes $=$ performance criteria .

1352 Figure 2: Proposed indicators under the Social Pillar of the Global Bioenergy Sustainability 1353 Partnership (GBEP). Source: ref 114. 
1355 Figure 1. Drivers and performance criteria for bioenergy value chains, from plot to global 1356 scales. Blue boxes $=$ drivers; orange boxes $=$ performance criteria .

1357

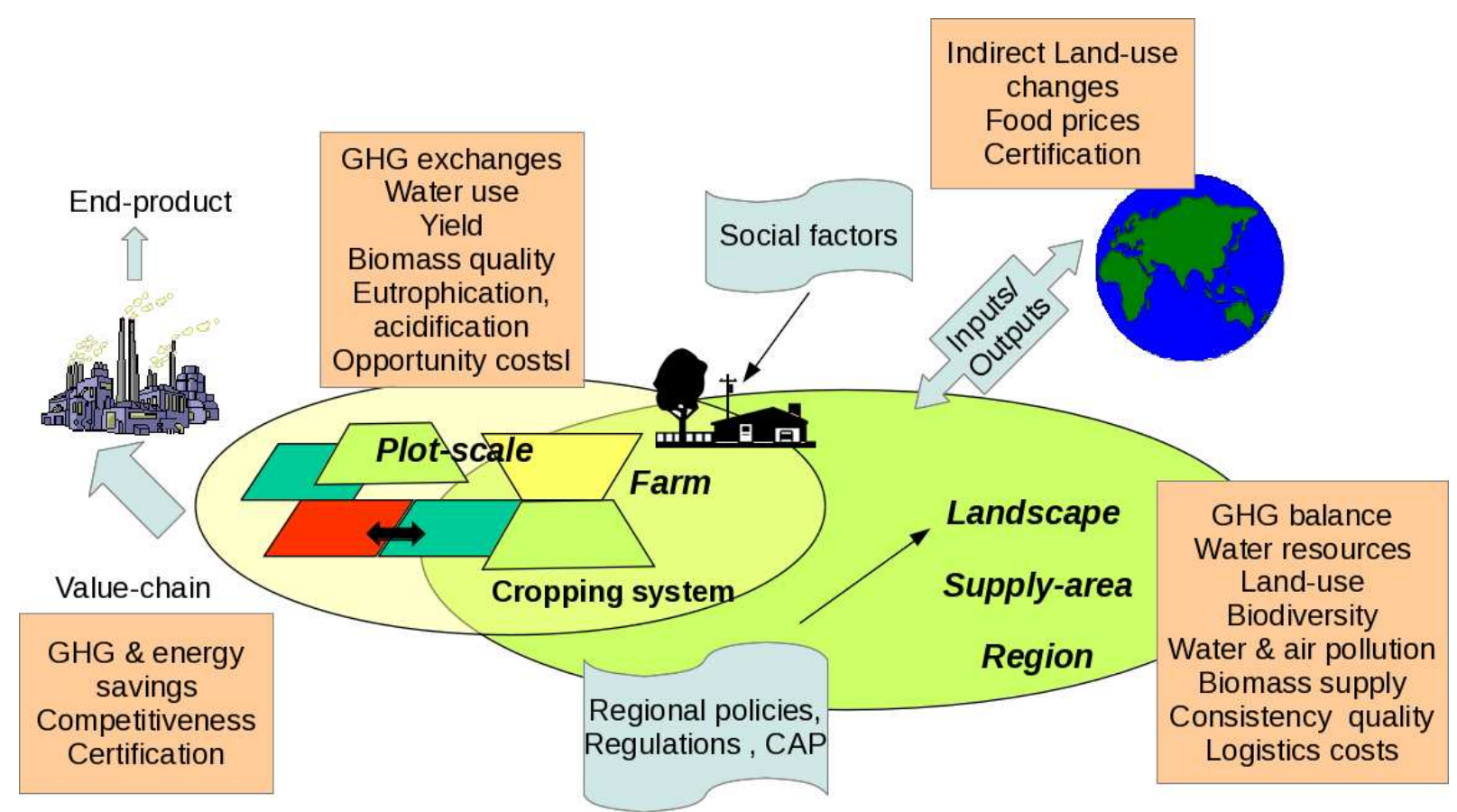


1370 Figure 2. Proposed indicators under the Social Pillar of the Global Bioenergy Sustainability

1371 Partnership (GBEP). Source: ref 114.

\begin{tabular}{|c|c|c|}
\hline \multicolumn{3}{|c|}{$\begin{array}{l}\text { PILLARS } \\
\begin{array}{l}\text { GBEP's work on sustainability indicators was developed under the following three pillars, } \\
\text { noting interlinkages between them: }\end{array}\end{array}$} \\
\hline Environmental & Social & Economic \\
\hline \multicolumn{3}{|c|}{$\begin{array}{l}\text { THEMES } \\
\text { GBEP considers the following themes relevant, and these guided the development of indicators under } \\
\text { these pillars: }\end{array}$} \\
\hline $\begin{array}{l}\text { Greenhouse gas emissions, } \\
\text { Productive capacity of the land } \\
\text { and ecosystems, Air quality. } \\
\text { Water availability, use efficiency } \\
\text { and quality. Biological diversity. } \\
\text { Land-use change, including } \\
\text { indirect effects. }\end{array}$ & $\begin{array}{l}\text { Price and supply of a national } \\
\text { food basket, Access to land, water } \\
\text { and other natural resources, } \\
\text { Labour conditions, Rural and } \\
\text { social develooment, Access to } \\
\text { energy. Human health and safety. }\end{array}$ & $\begin{array}{l}\text { Resource availability and use } \\
\text { efficiencies in bioenergy } \\
\text { production, conversion, } \\
\text { distribution and end use, } \\
\text { Economic development, } \\
\text { Economic viability and } \\
\text { competitiveness of bioenergy. } \\
\text { Access to technology and } \\
\text { technological capabilities, Energy } \\
\text { security/Diversification of sources } \\
\text { and supply. Energy } \\
\text { security/infrastructure and } \\
\text { logistics for distribution and use. }\end{array}$ \\
\hline \multicolumn{3}{|c|}{ INDICATORS } \\
\hline 1. Lifecycle GHG emissions & $\begin{array}{l}\text { 9. Allocation and tenure of land } \\
\text { for new bioenergy production }\end{array}$ & 17. Productivity \\
\hline 2. Sol quality & $\begin{array}{l}\text { 10. Price and supply of a national } \\
\text { food basket }\end{array}$ & 18. Net energy balance \\
\hline $\begin{array}{l}\text { 3. Harvest levels of wood } \\
\text { resources }\end{array}$ & 11. Change in income & 19. Gross value added \\
\hline $\begin{array}{l}\text { 4. Emissions of non-GHG air } \\
\text { pollutants, including air } \\
\text { toxics }\end{array}$ & 12. Jabs in the bioenergy sector & $\begin{array}{l}\text { 20. Change in consumption of } \\
\text { fossil fuels and traditional use } \\
\text { of biomass }\end{array}$ \\
\hline 5. Water use and efficiency & $\begin{array}{l}\text { 13. Change in unpaid time spent } \\
\text { by women and children } \\
\text { collecting biomass }\end{array}$ & $\begin{array}{l}\text { 21. Training and requalification of } \\
\text { the workforce }\end{array}$ \\
\hline 6. Water quality & $\begin{array}{l}\text { 14. Bioenergy used to expand } \\
\text { access to modern energy } \\
\text { services }\end{array}$ & 22. Energy diversity \\
\hline $\begin{array}{l}\text { 7. Biological diversity in the } \\
\text { landscape }\end{array}$ & $\begin{array}{l}\text { 15. Change in mortality and } \\
\text { burden of disease attributable } \\
\text { to indoor smoke }\end{array}$ & $\begin{array}{l}\text { 23. Infrastructure and logistics for } \\
\text { distribution of bicenergy }\end{array}$ \\
\hline $\begin{array}{l}\text { 8. Land use and land-use } \\
\text { change related to bioenergy } \\
\text { feedstock production }\end{array}$ & $\begin{array}{l}\text { 16. Incidence of occupational } \\
\text { injury, illness and fatalities }\end{array}$ & $\begin{array}{l}\text { 24. Capacity and flexibility of use } \\
\text { of bioenergy }\end{array}$ \\
\hline
\end{tabular}


1374 Table 1. Biomass and biofuel yields of arable crops, crop residues and dedicated 1375 lignocelllulosic crops

Biomass yields

(t DM ha $\left.{ }^{-1} \mathrm{yr}^{-1}\right)$
CYa

Biofuel yields

(toe ha- $\mathrm{yr}^{-1}$ )

\begin{tabular}{|c|c|c|c|c|c|c|c|}
\hline \multicolumn{8}{|c|}{ Arable crops: Current mean yields } \\
\hline & EU-27 & France & Somme & $\begin{array}{l}\text { toe } \\
\mathrm{t}^{-1} \mathrm{DM}\end{array}$ & EU-27 & France & $\begin{array}{l}\text { Somm } \\
\mathrm{e}\end{array}$ \\
\hline Winter wheat & 4.2 & 6.1 & 7.3 & 0.22 & 0.9 & 1.3 & 1.6 \\
\hline Maize & 5.7 & 7.4 & 7.9 & 0.23 & 1.3 & 1.7 & 1.8 \\
\hline Oilseed rape & 2.7 & 2.9 & 3.3 & 0.36 & 1 & 1 & 1.2 \\
\hline Sugar beet & 12.3 & 15.9 & 16 & 0.24 & 2.9 & 3.7 & 3.8 \\
\hline \multicolumn{8}{|c|}{$\begin{array}{l}\text { Crop residues: Estimated current mean } \\
\text { yields }\end{array}$} \\
\hline & EU-27 & France & Somme & $\begin{array}{c}\text { toe } \\
\mathrm{t}^{-1} \mathrm{DM}\end{array}$ & EU-27 & France & $\begin{array}{l}\text { Somm } \\
\mathrm{e}\end{array}$ \\
\hline Winter wheat & 4.6 & 5.8 & 6.5 & 0.16 & 0.7 & 0.9 & 1 \\
\hline Maize & 5.9 & 7.2 & 7.6 & 0.15 & 0.9 & 1.1 & 1.1 \\
\hline Oilseed rape & 4.4 & 4.6 & 4.9 & 0.15 & 0.6 & 0.7 & 0.7 \\
\hline
\end{tabular}

Conventional crops (whole plant): Total of conventional crops + crops residues

EU-27 France Somme

EU-27 France

Somm

\begin{tabular}{lcccccc} 
Winter wheat & 8.8 & 11.8 & 13.8 & 1.6 & 2.2 & 2.6 \\
Maize & 11.6 & 14.7 & 15.5 & 2.2 & 2.8 & 2.9 \\
Oilseed rape & 7.1 & 7.5 & 8.2 & 1.6 & 1.7 & 1.9 \\
\hline
\end{tabular}

Dedicated lignocelllulosic crops : Experi-

mental yields

\begin{tabular}{|c|c|c|c|c|c|}
\hline & France & Somme & & & France \\
\hline * & Regix* & B\&E & $\begin{array}{c}\text { toe } \\
t^{-1} \mathrm{DM}\end{array}$ & Literature* & Regix* \\
\hline
\end{tabular}

\begin{tabular}{|c|c|c|c|c|c|c|c|}
\hline Willow SRC & $9(5-11)$ & - & - & 0.16 & $\begin{array}{c}1.5(0.7- \\
1.8)\end{array}$ & - & - \\
\hline Poplar SRC & $6(2-10)$ & - & - & 0.15 & $\begin{array}{c}0.9(0.4- \\
1.5)\end{array}$ & - & - \\
\hline Miscanthus E & $29(14-60)$ & - & 27 & 0.16 & $\begin{array}{c}4.7(2.3- \\
9.7)\end{array}$ & - & 4.3 \\
\hline Miscanthus L & $15(5-43)$ & $\begin{array}{c}15(3- \\
23)\end{array}$ & 19 & 0.16 & $\begin{array}{c}2.4(0.8- \\
6.9)\end{array}$ & $\begin{array}{c}2.4(0.4- \\
3.7)\end{array}$ & 3.1 \\
\hline $\begin{array}{l}\text { Switchgrass } \\
\text { E }\end{array}$ & $12(1-22)$ & - & 19 & 0.15 & $\begin{array}{c}1.8(0.2- \\
3.3)\end{array}$ & - & 2.9 \\
\hline Switchrass L & & $\begin{array}{c}14(5- \\
19)\end{array}$ & 16 & 0.15 & & $\begin{array}{c}2.2(0.7- \\
3.0)\end{array}$ & 2.5 \\
\hline Fescue & $9(4-14)$ & $\begin{array}{c}11(3- \\
23)\end{array}$ & 10 & 0.12 & $\begin{array}{c}1.1(0.5- \\
1.7)\end{array}$ & $\begin{array}{c}1.3(0.3- \\
2.8)\end{array}$ & 1.2 \\
\hline Alfalfa & $11(1-17)$ & $14(3-$ & 12 & 0.09 & $1.0(0.1-$ & $1.2(0.2-$ & 1.0 \\
\hline
\end{tabular}


16)

Triticale

Fiber

sorghum
13 (5-16)

$13(3-$

19)

$14(5-$

23)
$1.5)$

12

0.18

13
$2.3(0.9$

2.9)

$3.5(2.1-$

5.7)
1.4)

$2.3(0.6-$

3.3)

$1.9(0.7-$

3.1)

1377 *median (min-max)

1378 a CY = conversion yield

1379 b Miscanthus and switchgrass: $\mathrm{E}=$ early harvest (September to November) and $\mathrm{L}=$ late 1380 harvest (January to April).

1381

1382 Biomass yields for conventional crops (grain yields) are from Eurostat mean yields (for the 1383 period 2000-2009) for EU-27 and Agreste mean yields (for the period 2000-2009) for France 1384 and Somme (sugar beet yields are calculated from fresh yields at $16 \%$ sugar content with an 1385 hypothesis of $20 \%$ dry matter content). Biomass yields for crop residues are calculated from 1386 grain yields and straw/grain ratios from ref. [29]. Biomass yields for dedicated 1387 lignocelllulosic crops are taken from:

1388 - Literature data: literature reviews and compilations of individual studies (ref 129 for willow; 1389 refs 129 and 130 for poplar; ref 31 for miscanthus; ref 131 for switchgrass; refs 34 and 132 1390 for fescue; ref 34 for alfalfa; refs 35, 37, and 35 and 133 for triticale; refs 36, 134 and 135 for 1391 fiber sorghum.

1392 - Regix: experimental network of the French research project Regix (10 sites located in 1393 northern, central and southern France, years 2007-2008; ref 27)

1394 - B\&E: INRA experimental site "Biomass \& Environment” located in the Somme department, 1395 years 2007-2010 [28]

1396 Biofuel yields were obtained by multiplying biomass yield by an actual (conventional crops) 1397 or a theoretical (other feedstocks) conversion yield (CY, see supplementary material). 
1398 Table 2: Mean N, P, K concentration and N/C, P/C, K/C removal per toe of biofuel produced 1399 for conventional crops, crop residues and dedicated lignocellulosic crops.

1400

\begin{tabular}{|c|c|c|c|c|c|c|}
\hline & \multicolumn{3}{|c|}{$\begin{array}{l}\text { Nutrient concentration } \\
\qquad\left(\mathrm{g} \mathrm{kg}^{-1} \mathrm{DM}\right)\end{array}$} & \multicolumn{3}{|c|}{$\begin{array}{l}\text { Nutrient removal per toe of biofuel } \\
\text { produced }\left(\mathrm{kg} \mathrm{toe}^{-1}\right)\end{array}$} \\
\hline & $\mathrm{N}$ & $\mathrm{P}$ & $\mathrm{K}$ & $\mathrm{N}$ & $\mathrm{P}$ & $\mathrm{K}$ \\
\hline \multicolumn{7}{|l|}{ Arable crops } \\
\hline Winter wheat & $20.3 \pm 2.6$ & 2.7 & $4.6 \pm 0.4$ & 91 & 12 & 21 \\
\hline Maize & $12.9 \pm 1.0$ & $2.9 \pm 0.8$ & $5.9 \pm 3.4$ & 47 & 11 & 22 \\
\hline Oilseed rape & $31.8 \pm 1.6$ & 6.0 & 7.8 & 79 & 15 & 19 \\
\hline$\underline{\text { Sugar beet }}$ & $7.9 \pm 2.0$ & 1.2 & 7.9 & 32 & 5 & 32 \\
\hline \multicolumn{7}{|l|}{ Crop residues } \\
\hline Winter wheat & $6.0 \pm 0.9$ & $0.7 \pm 0.3$ & $13.5 \pm 3.0$ & 37 & 4 & 83 \\
\hline Maize & $6.2 \pm 1.2$ & $1.0 \pm 0.4$ & $13.9 \pm 5.3$ & 42 & 7 & 96 \\
\hline Oilseed rape & $6.3 \pm 1.1$ & 0.8 & 13.7 & 42 & 6 & 93 \\
\hline \multicolumn{7}{|c|}{ Dedicated lignocelllulosic crops } \\
\hline Willow SRC & $4.8 \pm 0.9$ & $0.8 \pm 0.3$ & $2.1 \pm 0.7$ & 30 & 5 & 13 \\
\hline Poplar SRC & $5.2 \pm 1.4$ & $0.8 \pm 0.4$ & $3.3 \pm 0.7$ & 34 & 5 & 22 \\
\hline Miscanthus E & $5.3 \pm 0.5$ & $0.6 \pm 0.2$ & $7.3 \pm 1.8$ & 33 & 4 & 45 \\
\hline Miscanthus L & $3.3 \pm 0.9$ & $0.4 \pm 0.0$ & $5.0 \pm 1.2$ & 21 & 2 & 31 \\
\hline Switchgrass E & $6.9 \pm 2.1$ & $1.0 \pm 0.1$ & $7.5 \pm 1.9$ & 45 & 7 & 49 \\
\hline Switchgrass L & $4.4 \pm 1.4$ & $0.7 \pm 0.2$ & $3.2 \pm 1.6$ & 29 & 4 & 21 \\
\hline Fescue & $15.5 \pm 3.7$ & $2.4 \pm 0.3$ & $19.9 \pm 3.4$ & 129 & 20 & 165 \\
\hline Alfalfa & $27.2 \pm 2.5$ & $2.6 \pm 0.2$ & $21.4 \pm 3.6$ & 311 & 29 & 245 \\
\hline Triticale & $10.3 \pm 1.2$ & 2.0 & $8.8 \pm 1.2$ & 58 & 11 & 50 \\
\hline Fiber sorghum & $9.2 \pm 0.1$ & 1.8 & 12.3 & 70 & 14 & 93 \\
\hline
\end{tabular}

1401

1402

1403 Values (mean \pm standard error) for nutrient concentration are from refs 5, 27, 28, 35, 36, 37, 1404 133, 136, 137, 138, 139, 140, 141, 142, 143, 144, 145, 146, 147, 148, 149, 150, 151, 152, 1405 153, 154，155, 156, 157，158, 159，160, 161, and Machet, JM (INRA Laon), pers. Comm., 1406 2012,. Standard errors are calculated when three or more references are available for a given 1407 feedstock.

1408

1409 
1411 Table 3. Classification framework for biomass supply models. Key to land-use (LU) hypotheses: 1: a few studies make soft hypotheses;

1412 2: most studies make soft hypotheses; 3: studies make strong hypotheses (eg, food - feed - nature paradigm).

\begin{tabular}{|c|c|c|c|c|c|c|c|}
\hline & Group & SPATIAL & ECONOMICS & PLANT & $\begin{array}{l}\text { LU } \\
\text { Hypotheses }\end{array}$ & $\begin{array}{l}\text { Stakeholders/ } \\
\text { farmers } \\
\text { Behaviour }\end{array}$ & References \\
\hline \multirow[t]{3}{*}{$\begin{array}{l}\text { Group } 1 \\
\text { « Undriven }\end{array}$} & Group 1a & & & & 3 & & {$[99,100,162,163,164]$} \\
\hline & Group 1b & $\mathrm{X}$ & & & 3 & & $\begin{array}{l}{[101,102,103,165,166,167,} \\
168]\end{array}$ \\
\hline & Group 1c & $X$ & $X$ & & & & [169] \\
\hline \multirow{6}{*}{$\begin{array}{l}\text { Group } 2 \\
\text { «Driven » }\end{array}$} & Group 2a & & $X$ & & 1 & & {$[170,171,172]$} \\
\hline & Group 2b & $X$ & & & & & {$[173]$} \\
\hline & Group 2c & $\mathrm{X}$ & $X$ & & $\begin{array}{l}\text { (except } \\
\text { one)? }\end{array}$ & & {$[174,175,176,177]$} \\
\hline & Group 2d & $X$ & $X$ & $X$ & 2 & & $[61,95,178] 179,180,181]$, \\
\hline & Group 2e & $X$ & $X$ & $X$ & & & {$[182,183]$} \\
\hline & $\begin{array}{l}\text { Group } \\
2 \mathrm{f}\end{array}$ & $\mathrm{X}$ & $X$ & $\mathrm{X}$ & 2 & $\mathrm{X}$ & {$[105,106,184]$} \\
\hline
\end{tabular}


1413

1414

1415 


\section{Supplementary material}

1417

1418

1419

1420

1421 Table S1. Mean biomass composition and calculated conversion yield into ethanol of crop

1422 residues and dedicated bioenergy crops. For conventional crops, conversion yields were

1423 obtained from ref 185. For crop residues and dedicated bioenergy crops, conversion yields

1424 were calculated from averaged biomass composition of each feedstock and expected process

1425 efficiency for biological conversion of lignocellulose into ethanol [28]. For the energy content

1426 of biofuels, we used the following values: 0.89 toe $^{-1}$ biodiesel and 0.64 toe $\mathrm{t}^{-1}$ ethanol [4].

1427

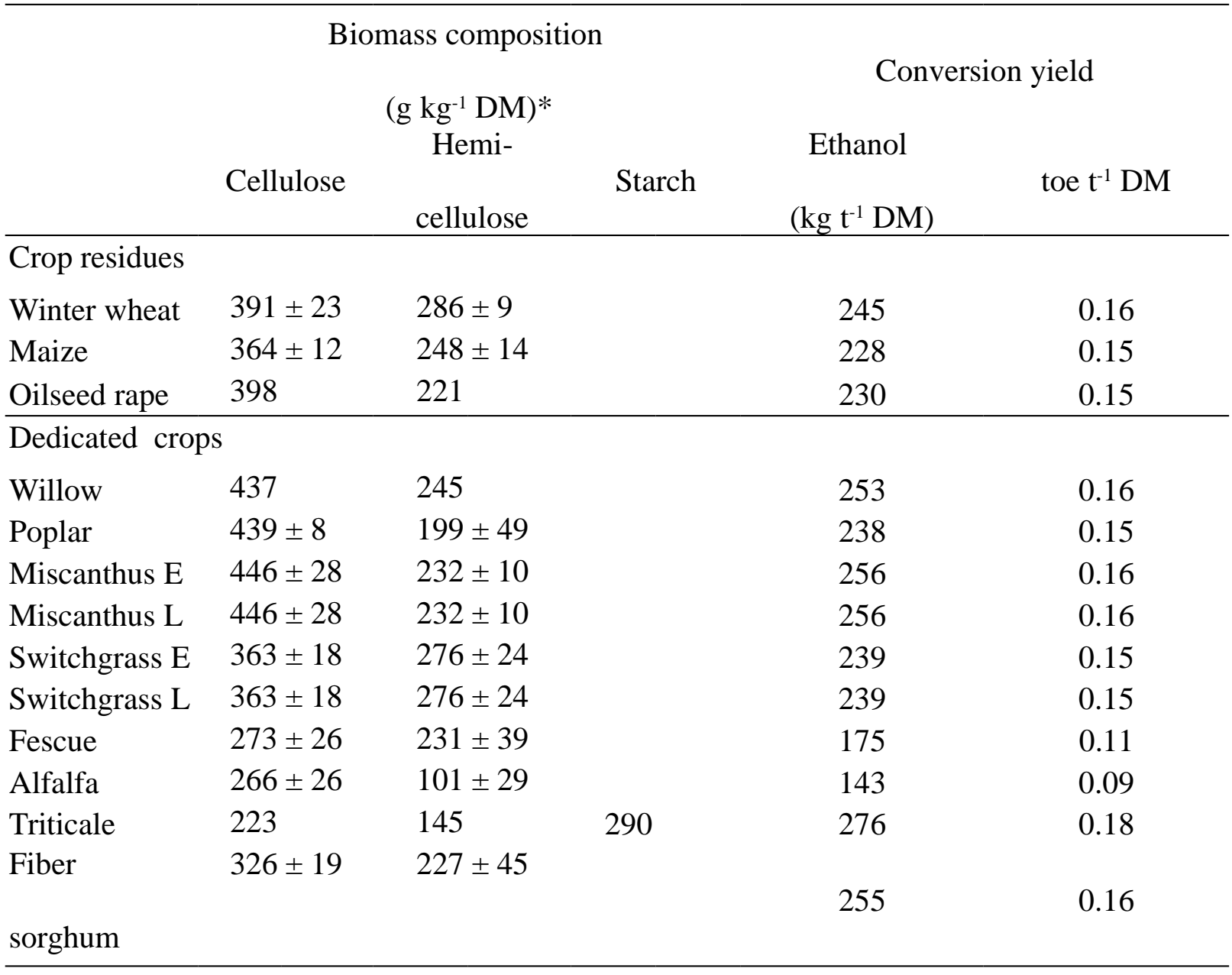

$1429 *$ Values (mean \pm standard error) are from refs 140, 141, 143, 148, 159, 186, 187, 188 and

1430 189. Standard errors are calculated when three or more references are available for a given

1431 feedstock. 